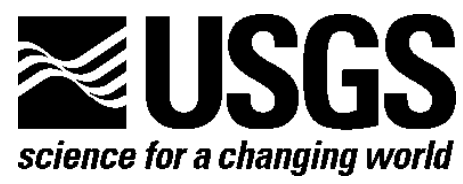

\title{
Input-Form Data for the U.S. Geological Survey Assessment of the Devonian and Mississippian Bakken and Devonian Three Forks Formations of the U.S. Williston Basin Province, 2013
}

By U.S. Geological Survey Bakken-Three Forks Assessment Team

Open-File Report 2013-1094

U.S. Department of the Interior

U.S. Geological Survey 


\section{U.S. Department of the Interior KEN SALAZAR, Secretary}

\section{U.S. Geological Survey \\ Suzette M. Kimball, Acting Director}

U.S. Geological Survey, Reston, Virginia: 2013

For more information on the USGS-the Federal source for science about the Earth, its natural and living resources, natural hazards, and the environment-visit http://www.usgs.gov or call 1-888-ASK-USGS

For an overview of USGS information products, including maps, imagery, and publications, visit $h$ ttp://www.usgs.gov/pubprod

To order this and other USGS information products, visit $h$ ttp://store.usgs.gov

Suggested citation:

U.S. Geological Survey Bakken-Three Forks Assessment Team, 2013, Input-form data for the U.S. Geological Survey assessment of the Devonian and Mississippian Bakken and Devonian Three Forks Formations of the U.S. Williston Basin Province, 2013: U.S. Geological Survey Open-File Report 20131094, 70 p., http://pubs.usgs.gov/of/2013/1094/.

Any use of trade, firm, or product names is for descriptive purposes only and does not imply endorsement by the U.S. Government.

Although this information product, for the most part, is in the public domain, it also may contain copyrighted materials as noted in the text. Permission to reproduce copyrighted items must be secured from the copyright owner. 


\section{Contents}

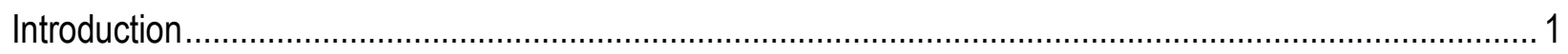

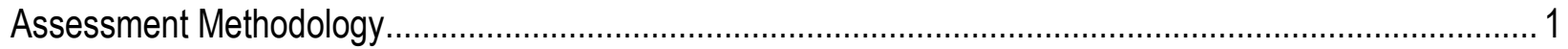

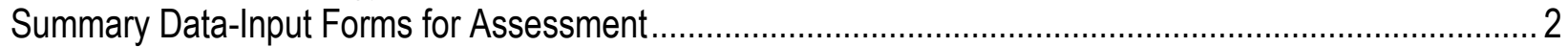

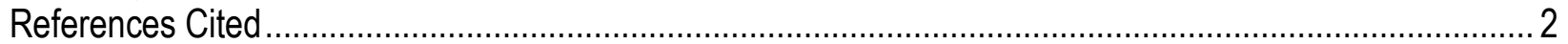

\section{Tables}

1. Input parameters for the Middle Bakken Conventional Assessment Unit (50310101), Bakken Total Petroleum System, Williston Basin Province.

2. Input parameters for the Three Forks Conventional Assessment Unit (50310103), Bakken Total Petroleum System, Williston Basin Province

3. Input parameters for the Elm Coulee-Billings Nose Continuous Oil Assessment Unit (50310161),

Bakken Total Petroleum System, Williston Basin Province .

4. Input parameters for the Central Basin Continuous Oil Assessment Unit (50310162), Bakken Total Petroleum System, Williston Basin Province

5. Input parameters for the Nesson-Little Knife Continuous Oil Assessment Unit (50310163), Bakken

Total Petroleum System, Williston Basin Province

6. Input parameters for the Eastern Transitional Continuous Oil Assessment Unit (50310164), Bakken

Total Petroleum System, Williston Basin Province

7. Input parameters for the Northwest Transitional Continuous Oil Assessment Unit (50310165),

Bakken Total Petroleum System, Williston Basin Province

8. Input parameters for the Three Forks Continuous Oil Assessment Unit (50310166), Bakken Total

Petroleum System, Williston Basin Province 


\title{
Input-Form Data for the U.S. Geological Survey Assessment of the Devonian and Mississippian Bakken and Devonian Three Forks Formations of the U.S. Williston Basin Province, 2013
}

\author{
By U.S. Geological Survey Bakken-Three Forks Assessment Team:
}

Stephanie B. Gaswirth, Kristen R. Marra, Troy A. Cook, Ronald R. Charpentier, Donald L. Gautier, Debra K. Higley, Timothy R. Klett, Michael D. Lewan, Paul G. Lillis, Christopher J. Schenk, Marilyn E. Tennyson, and Katherine J. Whidden

\section{Introduction}

In 2013, the U.S. Geological Survey (USGS) assessed the technically recoverable oil and gas resources of the Bakken and Three Forks Formations of the U.S. portion of the Williston Basin (Gaswirth and others, 2013). The Bakken and Three Forks Formations were assessed as continuous and hypothetical conventional oil accumulations using a methodology similar to that used in the assessment of other continuous- and conventional-type assessment units (AUs) throughout the United States. The purpose of this report is to provide supplemental documentation and information used in the Bakken-Three Forks assessment.

\section{Assessment Methodology}

The 2000 Energy Policy and Conservation Act legislation requires the USGS to assess the undiscovered, technically recoverable oil and gas resources of priority geologic provinces of the United States using an unbiased and scientific-based assessment methodology. The USGS developed two peer-reviewed methodologies, one for conventional resources and one for continuous resources. Since 2000, these methodologies have been used in the assessments of provinces throughout the United States. The methodology for the assessment of conventional and continuous resources is summarized in several documents (Klett and Charpentier, 2003; Crovelli, 2005; Klett and Schmoker, 2005; Klett and others, 2005; Schmoker, 2005; Schmoker and Klett, 2005; Charpentier and Cook, 2012).

The assessment team developed a geologic framework for the priority basins and assessment areas. They also completed statistically based summary data forms that include descriptive information for each geologic assessment unit. The data were subsequently used in the assessment calculations. 


\section{Summary Data-Input Forms for Assessment}

The data-input forms for the six Bakken Formation AUs (five continuous, one conventional) are provided in tables 1 and 3-7. The input forms for the two Three Forks AUs (one continuous, one conventional) are provided in tables 8 and 2.

\section{References Cited}

Charpentier, R.R. and Cook, T.A., 2012, Improved USGS methodology for assessing continuous petroleum resources, version 2.0: U.S. Geological Survey Data Series 547, 22 p.

Crovelli, R.A., 2005, Analytical resource method for continuous petroleum accumulations-The ACCESS assessment methodology, chap. 22 of USGS Southwestern Wyoming Province Assessment Team, Petroleum systems and geologic assessment of the Southwestern Wyoming Province, Wyoming, Colorado, and Utah: U.S. Geological Survey Digital Data Series DDS69-D, $10 \mathrm{p}$.

Gaswirth, S.B., Marra, K.R., Cook, T.A., Charpentier, R.R., Gautier, D.L., Higley, D.K., Klett, T.R., Lewan, M.D., Lillis, P.G., Schenk, C.J., Tennyson, M.E., and Whidden, K.J., 2013, Assessment of undiscovered oil resources in the Bakken and Three Forks Formations, Williston Basin Province, Montana, North Dakota, and South Dakota, 2013: U.S. Geological Survey Fact Sheet 2013-3013, 4 p.

IHS Energy Group, 2012, Petroleum Information/Dwights petroROM Rocky Mountain Region production data on CD-ROM: IHS Energy Group, 15 Inverness Way East, D205, Englewood, CO, 80112, U.S.A.

Klett, T.R., and Charpentier, R.R., 2003, FORSPAN Model users guide: U.S. Geological Survey Open-File Report 2003-354, 37 p.

Klett, T.R., and Schmoker, J.W., 2005, Input-data form and operational procedure for the assessment of continuous accumulations, 2002, chap. 18 of USGS Southwestern Wyoming Province Assessment Team, Petroleum systems and geologic assessment of the Southwestern Wyoming Province, Wyoming, Colorado, and Utah: U.S. Geological Survey Digital Data Series DDS-69-D, 8 p.

Klett, T.R., Schmoker, J.W., and Charpentier, R.R., 2005, U.S. Geological Survey input-data form and operational procedure for the assessment of conventional petroleum accumulations, chap. 20 of USGS Southwestern Wyoming Province Assessment Team, Petroleum systems and geologic assessment of the Southwestern Wyoming Province, Wyoming, Colorado, and Utah: U.S. Geological Survey Digital Data Series DDS-69-D, 7 p.

NRG Associates, 2010, The significant oil and gas fields of the United States: NRG Associates, Inc., database available from NRG Associates, Inc., P.O Box 1655, Colorado Springs, CO 80901, U.S.A.

Pollastro, R.M., Cook, T.A., Roberts, L.N.R., Schenk, C.J., Lewan, M.D., Anna, L.O., Gaswirth, S.B., Lillis, P.G., Klett, T.R., and Charpentier, R.R., 2008, Assessment of undiscovered oil resources in the Devonian-Mississippian Bakken Formation, Williston Basin Province, Montana and North Dakota, 2008: U.S. Geological Survey Fact Sheet 2008-3021, 2 p.

Schmoker, J.W., 2005, U.S. Geological Survey assessment concepts for continuous petroleum accumulations, chap. 13 of USGS Southwestern Wyoming Province Assessment Team, Petroleum systems and geologic assessment of the Southwestern Wyoming Province, Wyoming, Colorado, and Utah: U.S. Geological Survey Data Series DDS-69-D, 7 p. 
Schmoker, J.W., and Klett, T.R., 2005, U.S. Geological Survey assessment concepts for conventional petroleum accumulations, chap. 19 of USGS Southwestern Wyoming Province Assessment Team, Petroleum systems and geologic assessment of the Southwestern Wyoming Province, Wyoming, Colorado, and Utah: U.S. Geological Survey Data Series DDS-69-D, $6 \mathrm{p}$. 
Table 1. Input parameters for the Middle Bakken Conventional Assessment Unit (50310101), Bakken Total Petroleum System, Williston Basin Province. [bcfg, billion cubic feet of gas; mmcfg, million cubic feet of gas; cfg, cubic feet of gas; mmbo, million barrels of oil; mmboe, million barrels of oil equivalent; bo, barrel of oil; bliq, barrel of liquid; bngl, barrel of natural gas liquids; m, meters; AU, assessment unit]

\section{SEVENTH APPROXIMATION \\ DATA FORM FOR CONVENTIONAL ASSESSMENT UNITS (Version 6, 9 April 2003)}

\begin{tabular}{|c|c|c|c|}
\hline \multicolumn{4}{|c|}{ IDENTIFICATION INFORMATION } \\
\hline Assessment Geologist: & S. Gaswirth & Date: & 29-Jan-13 \\
\hline Region: & North America & Number: & 5 \\
\hline Province: & Williston Basin & Number: & 5031 \\
\hline Total Petroleum System: & Bakken & Number: & 503101 \\
\hline Assessment Unit: & Middle Bakken Conventional & Number: & 50310101 \\
\hline Based on Data as of: & IHS Energy Group (2012), NRG Associates (2010) & & \\
\hline Notes from Assessor: & $\begin{array}{l}\text { Ancillary data from Pollastro (2008), Saskatchewan } \\
\text { analog }\end{array}$ & kken pool & izes used as \\
\hline
\end{tabular}

\section{CHARACTERISTICS OF ASSESSMENT UNIT}

Oil ( $<20,000 \mathrm{cfg} / \mathrm{bo}$ overall) or Gas $(\geq 20,000 \mathrm{cfg} / \mathrm{bo}$ overall): _ _ Oil

What is the minimum accumulation size? $\quad 0.5 \quad$ mmboe grown

(the smallest accumulation that has potential to be added to reserves)

No. of discovered accumulations exceeding minimum size:

Established (>13 accums.)

Frontier (1-13 accums.)

Oil: 0 Gas: Hypothetical (no accum:)

$\frac{0}{\mathrm{X}}$

Median size (grown) of discovered oil accumulations (mmbo):

1st 3rd

Median size (grown) of discovered gas accumulations (bcfg):

1 st 3rd

2nd 3rd

3rd 3rd

2nd 3rd

3rd 3rd

\section{Assessment-Unit Probabilities:}

Attribute

Probability of occurrence (0-1.0)

1. CHARGE: Adequate petroleum charge for an undiscovered accum. $\geq$ minimum size:

2. ROCKS: Adequate reservoirs, traps, and seals for an undiscovered accum. $\geq$ minimum size:

3. TIMING OF GEOLOGIC EVENTS: Favorable timing for an undiscoverd accum. $\geq$ minimum size:

$\begin{array}{r}1.0 \\ \hline 1.0 \\ \hline 1.0 \\ \hline\end{array}$

Assessment-Unit GEOLOGIC Probability (Product of 1, 2, and 3):

1.0

\section{UNDISCOVERED ACCUMULATIONS}

No. of Undiscovered Accumulations: How many undiscovered accums. exist that are $\geq$ min. size?: (uncertainty of fixed but unknown values)

Oil Accumulations:

Gas Accumulations:

\begin{tabular}{l}
$\operatorname{minimum}(>0)$ \\
$\operatorname{minimum}(>0)$ \\
\hline
\end{tabular}

mode mode $\frac{0}{0}$ maximum 10

Sizes of Undiscovered Accumulations: What are the sizes (grown) of the above accums?: (variations in the sizes of undiscovered accumulations)

Oil in Oil Accumulations (mmbo):

Gas in Gas Accumulations (bcfg):

$\operatorname{minimum}$
minimum

median

0.8 maximum 10 maximum 


\section{AVERAGE RATIOS FOR UNDISCOVERED ACCUMS., TO ASSESS COPRODUCTS}

(uncertainty of fixed but unknown values)

Oil Accumulations:

Gas/oil ratio (cfg/bo)

$\mathrm{NGL} / \mathrm{gas}$ ratio (bngl/mmcfg)

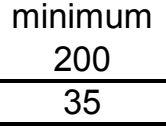

minimum mode

400

85

mode maximum

600

115

Gas Accumulations:

Liquids/gas ratio (bliq/mmcfg)

Oil/gas ratio (bo/mmcfg)

\section{SELECTED ANCILLARY DATA FOR UNDISCOVERED ACCUMULATIONS}

(variations in the properties of undiscovered accumulations)

Oil Accumulations:

API gravity (degrees)

Sulfur content of oil (\%)

Depth $(m)$ of water (if applicable)

Drilling Depth $(m)$

Gas Accumulations:

Inert gas content (\%)

$\mathrm{CO}_{2}$ content $(\%)$

Hydrogen-sulfide content (\%)

Depth $(\mathrm{m})$ of water (if applicable)

Drilling Depth (m) minimum

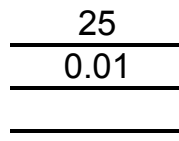

minimum

750

minimum

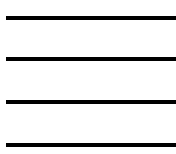

minimum mode

40

0.1

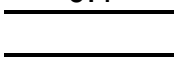

F75

mode

2000

F25

maximum

2750

50

1

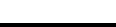

maximum

mode

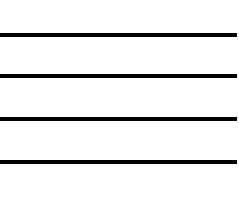

F75

maximum 


\section{ALLOCATIONS OF POTENTIAL ADDITIONS TO RESERVES TO STATES \\ Surface Allocations (uncertainty of a fixed value)}

1. Montana

Oil in Oil Accumulations:

Volume $\%$ in entity

Gas in Gas Accumulations:

Volume \% in entity

2. North Dakota

Oil in Oil Accumulations:

Volume \% in entity

Gas in Gas Accumulations:

Volume $\%$ in entity

3.

Oil in Oil Accumulations:

Volume $\%$ in entity

Gas in Gas Accumulations:

Volume \% in entity

4.

Oil in Oil Accumulations:

Volume \% in entity

Gas in Gas Accumulations:

Volume $\%$ in entity

5.

Oil in Oil Accumulations:

Volume $\%$ in entity

Gas in Gas Accumulations:

Volume $\%$ in entity

6.

Oil in Oil Accumulations:

Volume \% in entity

Gas in Gas Accumulations:

Volume \% in entity

represents 15.76 area \% of the $\mathrm{AU}$

minimum

$\overline{ }$

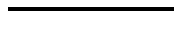

$\longrightarrow$ represents

84.24 area $\%$ of the $\mathrm{AU}$

minimum

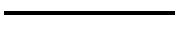

mode

85.00

mode

15.00 maximum

-




\section{ALLOCATIONS OF POTENTIAL ADDITIONS TO RESERVES TO LAND ENTITIES Surface Allocations (uncertainty of a fixed value)}

1. Federal Lands

Oil in Oil Accumulations:

Volume \% in entity

Gas in Gas Accumulations:

Volume $\%$ in entity

2. Private Lands

Oil in Oil Accumulations:

Volume $\%$ in entity

Gas in Gas Accumulations:

Volume $\%$ in entity

3. Tribal Lands

Oil in Oil Accumulations:

Volume $\%$ in entity

Gas in Gas Accumulations:

Volume \% in entity

4. Other Lands

Oil in Oil Accumulations:

Volume $\%$ in entity

Gas in Gas Accumulations:

Volume $\%$ in entity

5. MT State Lands

Oil in Oil Accumulations:

Volume \% in entity

Gas in Gas Accumulations:

Volume $\%$ in entity

6. ND State Lands

Oil in Oil Accumulations:

Volume \% in entity

Gas in Gas Accumulations:

Volume \% in entity

represents 8.55 area $\%$ of the $\mathrm{AU}$

minimum

$\overline{ }$

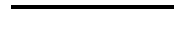

$\longrightarrow$ represents

83.42

mode

83.00 mode

9.00 maximum

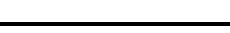




\section{ALLOCATIONS OF POTENTIAL ADDITIONS TO RESERVES TO FEDERAL LAND SUBDIVISIONS Surface Allocations (uncertainty of a fixed value)}

1. Bureau of Land Management (BLM)

Oil in Oil Accumulations:

Volume \% in entity

Gas in Gas Accumulations:

Volume $\%$ in entity

2. BLM Wilderness Areas (BLMW)

Oil in Oil Accumulations:

Volume \% in entity

Gas in Gas Accumulations:

Volume $\%$ in entity

3. BLM Roadless Areas (BLMR)

Oil in Oil Accumulations:

Volume $\%$ in entity

Gas in Gas Accumulations:

Volume $\%$ in entity

4. National Park Service (NPS)

Oil in Oil Accumulations:

Volume $\%$ in entity

Gas in Gas Accumulations:

Volume $\%$ in entity

5. NPS Wilderness Areas (NPSW)

Oil in Oil Accumulations:

Volume \% in entity

Gas in Gas Accumulations:

Volume \% in entity

6. NPS Protected Withdrawals (NPSP)

Oil in Oil Accumulations:

Volume \% in entity

Gas in Gas Accumulations:

Volume \% in entity

represents 4.88 area $\%$ of the $\mathrm{AU}$

minimum

$\overline{ }$

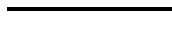

$\longrightarrow$ represents

mode

5.00 maximum

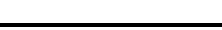


7. US Forest Service (FS)

Oil in Oil Accumulations:

Volume $\%$ in entity

Gas in Gas Accumulations:

Volume $\%$ in entity

8. USFS Wilderness Areas (FSW)

Oil in Oil Accumulations:

Volume $\%$ in entity

Gas in Gas Accumulations:

Volume $\%$ in entity

9. USFS Roadless Areas (FSR)

Oil in Oil Accumulations:

Volume $\%$ in entity

Gas in Gas Accumulations:

Volume $\%$ in entity

10. USFS Protected Withdrawals (FSP)

Oil in Oil Accumulations:

Volume \% in entity

Gas in Gas Accumulations:

Volume $\%$ in entity

11. US Fish and Wildlife Service (FWS)

Oil in Oil Accumulations:

Volume $\%$ in entity

Gas in Gas Accumulations:

Volume $\%$ in entity

12. USFWS Wilderness Areas (FWSW)

Oil in Oil Accumulations:

Volume \% in entity

Gas in Gas Accumulations:

Volume $\%$ in entity represents

0.01
area $\%$ of the $\mathrm{AU}$

minimum

mode

maximum

0.00
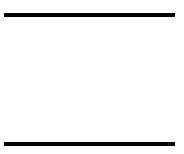
represents area $\%$ of the $\mathrm{AU}$

\section{minimum}

mode

maximum
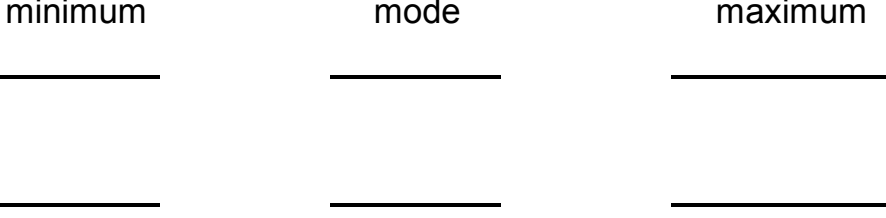
represents area $\%$ of the $\mathrm{AU}$

minimum

mode

maximum

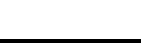

maximum
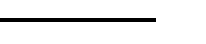

$$
\text { (1) }
$$
represents area $\%$ of the $\mathrm{AU}$

minimum

mode

maximum
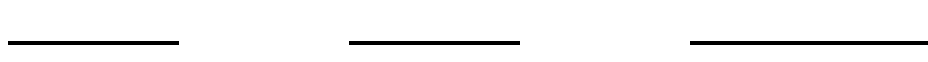

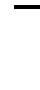

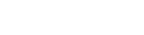
represents 1.88 area $\%$ of the $\mathrm{AU}$

minimum

mode

maximum

2.00 represents area $\%$ of the $\mathrm{AU}$

minimum

mode

maximum 
13. USFWS Protected Withdrawals (FWSP)

Oil in Oil Accumulations:

Volume $\%$ in entity

Gas in Gas Accumulations:

Volume $\%$ in entity

14. Wilderness Study Areas (WS)

Oil in Oil Accumulations:

Volume $\%$ in entity

Gas in Gas Accumulations:

Volume $\%$ in entity

15. Department of Energy (DOE)

Oil in Oil Accumulations:

Volume $\%$ in entity

Gas in Gas Accumulations:

Volume $\%$ in entity

16. Department of Defense (DOD)

Oil in Oil Accumulations:

Volume \% in entity

Gas in Gas Accumulations:

Volume $\%$ in entity

17. Bureau of Reclamation (BOR)

Oil in Oil Accumulations:

Volume $\%$ in entity

Gas in Gas Accumulations:

Volume $\%$ in entity

18. Tennessee Valley Authority (TVA)

Oil in Oil Accumulations:

Volume \% in entity

Gas in Gas Accumulations:

Volume $\%$ in entity represents

area $\%$ of the $\mathrm{AU}$

minimum

mode

maximum
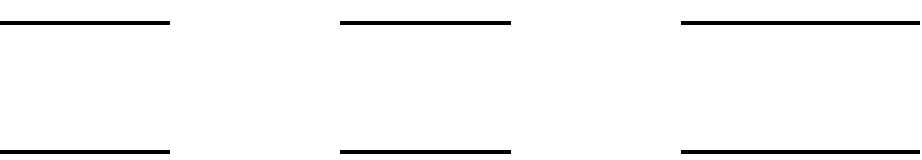
represents area $\%$ of the $\mathrm{AU}$

minimum

mode

maximum

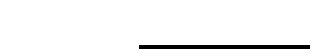

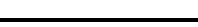
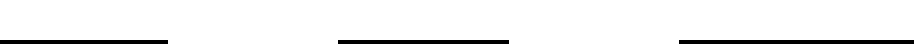
represents area $\%$ of the $\mathrm{AU}$

minimum

mode

maximum

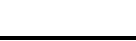

mode maximum


19. Other Federal

Oil in Oil Accumulations:

Volume \% in entity

Gas in Gas Accumulations:

Volume $\%$ in entity

20.

Oil in Oil Accumulations:

Volume $\%$ in entity

Gas in Gas Accumulations:

Volume \% in entity represents

1.76 area $\%$ of the $\mathrm{AU}$

minimum

mode

2.00

maximum
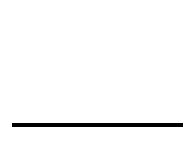
represents area $\%$ of the $\mathrm{AU}$

minimum mode

maximum

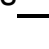

area $\%$ of the AU

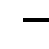

-

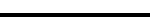

- 


\section{ALLOCATIONS OF POTENTIAL ADDITIONS TO RESERVES TO ECOSYSTEMS Surface Allocations (uncertainty of a fixed value)}

1. Northeastern Glaciated Plains (NEGP)

Oil in Oil Accumulations:

Volume $\%$ in entity

Gas in Gas Accumulations:

Volume \% in entity

2. Northern Glaciated Plains (NGPL)

Oil in Oil Accumulations:

Volume \% in entity

Gas in Gas Accumulations:

Volume $\%$ in entity

3. Northwestern Glaciated Plains (NWGL)

Oil in Oil Accumulations:

Volume $\%$ in entity

Gas in Gas Accumulations:

Volume $\%$ in entity

4. Northwestern Great Plains (NWGP)

Oil in Oil Accumulations:

Volume \% in entity

Gas in Gas Accumulations:

Volume \% in entity

5.

Oil in Oil Accumulations:

Volume \% in entity

Gas in Gas Accumulations:

Volume \% in entity

6.

Oil in Oil Accumulations:

Volume $\%$ in entity

Gas in Gas Accumulations:

Volume $\%$ in entity

represents 52.98 area \% of the AU

minimum

$\overline{-}$

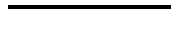

$\overline{-}$ represents

22.92
area $\%$ of the $\mathrm{AU}$

minimum

mode

maximum

23.00
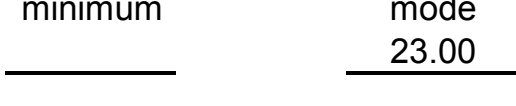

$+$ represents

15.75 area $\%$ of the AU

minimum

mode

maximum

16.00

$\overline{-10}$

mode
16.00 $\quad$ maximum

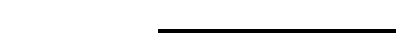


Table 2. Input parameters for the Three Forks Conventional Assessment Unit (50310103), Bakken Total Petroleum System, Williston Basin Province. [bcfg, billion cubic feet of gas; mmcfg, million cubic feet of gas; cfg, cubic feet of gas; mmbo, million barrels of oil; mmboe, million barrels of oil equivalent; bo, barrel of oil; bliq, barrel of liquid; bngl, barrel of natural gas liquids; m, meters; AU, assessment unit]

\section{SEVENTH APPROXIMATION \\ DATA FORM FOR CONVENTIONAL ASSESSMENT UNITS (Version 6, 9 April 2003)}

Assessment Geologist:

Region:

Province:

Total Petroleum System:

Assessment Unit:

Based on Data as of:

Notes from Assessor:

\section{IDENTIFICATION INFORMATION}

K. Marra

North America

Williston Basin

Bakken

Three Forks Conventional

IHS Energy Group (2012), NRG Associates (2010)

Ancillary data from Pollastro (2008), Saskatchewan Bakken pool sizes used as
Date: 29-Jan-13

Number: 5

Number: 5031

Number: 503101

Number: 50310103

\section{CHARACTERISTICS OF ASSESSMENT UNIT}

Oil ( $<20,000 \mathrm{cfg} / \mathrm{bo}$ overall) or Gas $(\geq 20,000 \mathrm{cfg} / \mathrm{bo}$ overall): _ _ Oil

What is the minimum accumulation size?

0.5 mmboe grown

(the smallest accumulation that has potential to be added to reserves)

No. of discovered accumulations exceeding minimum size:

Established (>13 accums.)
Frontier (1-13 accums.)

Oil:

0 Hypothetical (no accums:)

Median size (grown) of discovered oil accumulations ( $\mathrm{mmbo}$ ):

1 st 3rd

2nd 3rd

3rd 3rd

Median size (grown) of discovered gas accumulations (bcfg):

1 st 3 rd

2nd 3rd

3rd 3rd

\section{Assessment-Unit Probabilities:}

Attribute

Probability of occurrence (0-1.0)

1. CHARGE: Adequate petroleum charge for an undiscovered accum. $\geq$ minimum size:

2. ROCKS: Adequate reservoirs, traps, and seals for an undiscovered accum. $\geq$ minimum size:

3. TIMING OF GEOLOGIC EVENTS: Favorable timing for an undiscovered accum. $\geq$ minumum size:

\begin{tabular}{l}
0.7 \\
\hline 1.0 \\
\hline 1.0 \\
\hline
\end{tabular}

Assessment-Unit GEOLOGIC Probability (Product of 1, 2, and 3):

0.7

\section{UNDISCOVERED ACCUMULATIONS}

No. of Undiscovered Accumulations: How many undiscovered accums. exist that are $\geq$ min. size?:

(uncertainty of fixed but unknown values)

Oil Accumulations:

Gas Accumulations:

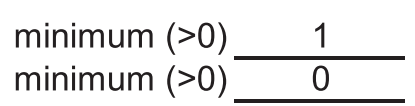

mode mode $\frac{2}{0}$ maximum

$\frac{10}{0}$

Sizes of Undiscovered Accumulations: What are the sizes (grown) of the above accums?:

(variations in the sizes of undiscovered accumulations)

Oil in Oil Accumulations (mmbo):

Gas in Gas Accumulations (bcfg): minimum $\quad 0.5$

minimum median

median maximum maximum
5 


\section{AVERAGE RATIOS FOR UNDISCOVERED ACCUMS., TO ASSESS COPRODUCTS}

(uncertainty of fixed but unknown values)

Oil Accumulations:

Gas/oil ratio (cfg/bo)

NGL/gas ratio (bngl/mmcfg)

\begin{tabular}{c}
$\begin{array}{c}\text { minimum } \\
200\end{array}$ \\
\hline 35 \\
\hline
\end{tabular}

minimum mode

400

85

mode maximum 600

115

Gas Accumulations:

Liquids/gas ratio (bliq/mmcfg)

Oil/gas ratio (bo/mmcfg)

\section{SELECTED ANCILLARY DATA FOR UNDISCOVERED ACCUMULATIONS}

(variations in the properties of undiscovered accumulations)

Oil Accumulations:

API gravity (degrees)

Sulfur content of oil (\%)

Depth $(m)$ of water (if applicable)

Drilling Depth (m)

Gas Accumulations:

Inert gas content (\%)

$\mathrm{CO}_{2}$ content (\%)

Hydrogen-sulfide content (\%)

Depth (m) of water (if applicable)

Drilling Depth (m) minimum

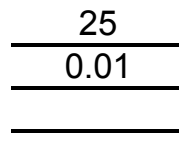

mode

\begin{tabular}{ccccc}
$\begin{array}{c}\text { minimum } \\
1250\end{array}$ & $F 75$ & $\begin{array}{c}\text { mode } \\
2200\end{array}$ & F25 & $\begin{array}{c}\text { maximum } \\
3100\end{array}$ \\
\hline
\end{tabular}

minimum

mode

maximum

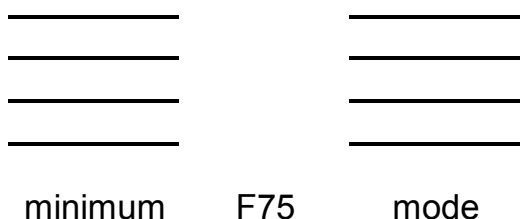

minimum $\mathrm{F} 75$ mode $\mathrm{F} 25$ maximum maximum

50

1

ximum maximum

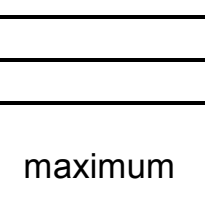




\section{ALLOCATIONS OF POTENTIAL ADDITIONS TO RESERVES TO STATES \\ Surface Allocations (uncertainty of a fixed value)}

1. Montana

Oil in Oil Accumulations:

Volume $\%$ in entity

Gas in Gas Accumulations:

Volume \% in entity

2. North Dakota

Oil in Oil Accumulations:

Volume $\%$ in entity

Gas in Gas Accumulations:

Volume $\%$ in entity

3. South Dakota

Oil in Oil Accumulations:

Volume $\%$ in entity

Gas in Gas Accumulations:

Volume $\%$ in entity

4.

Oil in Oil Accumulations:

Volume \% in entity

Gas in Gas Accumulations:

Volume $\%$ in entity

5.

Oil in Oil Accumulations:

Volume \% in entity

Gas in Gas Accumulations:

Volume $\%$ in entity

6.

Oil in Oil Accumulations:

Volume \% in entity

Gas in Gas Accumulations:

Volume $\%$ in entity

represents 24.20 area $\%$ of the $\mathrm{AU}$

minimum

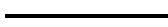

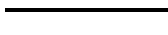

$\longrightarrow$ represents

45.54 area $\%$ of the $\mathrm{AU}$

minimum

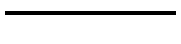

mode

75.00

mode

20.00 maximum

-




\section{ALLOCATIONS OF POTENTIAL ADDITIONS TO RESERVES TO LAND ENTITIES Surface Allocations (uncertainty of a fixed value)}

1. Federal Lands

Oil in Oil Accumulations:

Volume $\%$ in entity

Gas in Gas Accumulations:

Volume \% in entity

2. Private Lands

Oil in Oil Accumulations:

Volume $\%$ in entity

Gas in Gas Accumulations:

Volume $\%$ in entity

3. Tribal Lands

Oil in Oil Accumulations:

Volume $\%$ in entity

Gas in Gas Accumulations:

Volume $\%$ in entity

4. Other Lands

Oil in Oil Accumulations:

Volume $\%$ in entity

Gas in Gas Accumulations:

Volume $\%$ in entity

5. MT State Lands

Oil in Oil Accumulations:

Volume $\%$ in entity

Gas in Gas Accumulations:

Volume $\%$ in entity

6. ND State Lands

Oil in Oil Accumulations:

Volume $\%$ in entity

minimum represents

2.18 area $\%$ of the $\mathrm{AU}$

Gas in Gas Accumulations:

Volume $\%$ in entity represents 6.02 area $\%$ of the $\mathrm{AU}$ minimum

$\overline{-}$

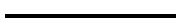
represents

82.62 area $\%$ of the $\mathrm{AU}$

minimum

mode

83.00 $\longrightarrow$ maximum

6.00 represents 5.71 area \% of the $\mathrm{AU}$

minimum

mode

maximum

6.00

represents 0.68 area $\%$ of the $\mathrm{AU}$

minimum

mode

maximum maximum 
7. SD State Lands

Oil in Oil Accumulations:

Volume $\%$ in entity

Gas in Gas Accumulations:

Volume $\%$ in entity

8.

Oil in Oil Accumulations:

Volume $\%$ in entity

Gas in Gas Accumulations:

Volume $\%$ in entity

9.

Oil in Oil Accumulations:

Volume $\%$ in entity

Gas in Gas Accumulations:

Volume $\%$ in entity

10.

Oil in Oil Accumulations:

Volume $\%$ in entity

Gas in Gas Accumulations:

Volume $\%$ in entity

11.

Oil in Oil Accumulations:

Volume $\%$ in entity

Gas in Gas Accumulations:

Volume $\%$ in entity

12.

Oil in Oil Accumulations:

Volume $\%$ in entity

Gas in Gas Accumulations:

Volume $\%$ in entity represents

1.38 area $\%$ of the $\mathrm{AU}$

minimum

mode

maximum

1.00
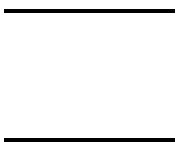
represents area $\%$ of the $\mathrm{AU}$

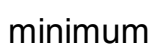

mode

maximum
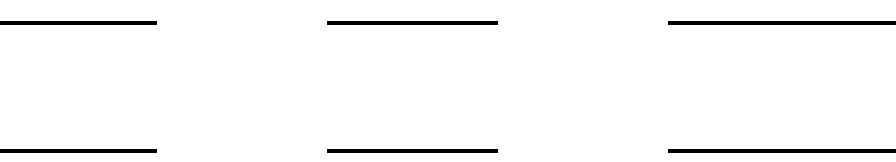
represents area $\%$ of the AU

minimum

mode

maximum

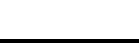

maximum
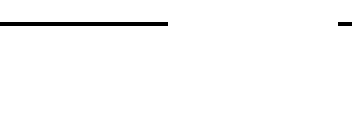

represents area $\%$ of the $\mathrm{AU}$

minimum

mode

maximum
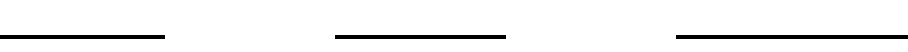

minimum

represents area $\%$ of the $\mathrm{AU}$

mode

maximum represents area $\%$ of the $\mathrm{AU}$

minimum

mode maximum 


\section{ALLOCATIONS OF POTENTIAL ADDITIONS TO RESERVES TO FEDERAL LAND SUBDIVISIONS Surface Allocations (uncertainty of a fixed value)}

1. Bureau of Land Management (BLM)

Oil in Oil Accumulations:

Volume $\%$ in entity

Gas in Gas Accumulations:

Volume \% in entity

2. BLM Wilderness Areas (BLMW)

Oil in Oil Accumulations:

Volume $\%$ in entity

Gas in Gas Accumulations:

Volume $\%$ in entity

3. BLM Roadless Areas (BLMR)

Oil in Oil Accumulations:

Volume $\%$ in entity

Gas in Gas Accumulations:

Volume $\%$ in entity

4. National Park Service (NPS)

Oil in Oil Accumulations:

Volume $\%$ in entity

Gas in Gas Accumulations:

Volume $\%$ in entity

5. NPS Wilderness Areas (NPSW)

Oil in Oil Accumulations:

Volume $\%$ in entity

Gas in Gas Accumulations:

Volume $\%$ in entity

6. NPS Protected Withdrawals (NPSP)

Oil in Oil Accumulations:

Volume $\%$ in entity

Gas in Gas Accumulations:

Volume $\%$ in entity

represents 2.73 area $\%$ of the $\mathrm{AU}$

minimum

$\overline{-10}$

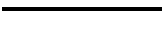

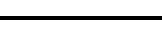
represents

mode

3.00 maximum

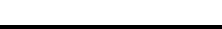


7. US Forest Service (FS)

Oil in Oil Accumulations:

Volume $\%$ in entity

Gas in Gas Accumulations:

Volume $\%$ in entity

8. USFS Wilderness Areas (FSW)

Oil in Oil Accumulations:

Volume $\%$ in entity

Gas in Gas Accumulations:

Volume $\%$ in entity

9. USFS Roadless Areas (FSR)

Oil in Oil Accumulations:

Volume $\%$ in entity

Gas in Gas Accumulations:

Volume $\%$ in entity

10. USFS Protected Withdrawals (FSP)

Oil in Oil Accumulations:

Volume $\%$ in entity

Gas in Gas Accumulations:

Volume $\%$ in entity

11. US Fish and Wildlife Service (FWS)

Oil in Oil Accumulations:

Volume $\%$ in entity

Gas in Gas Accumulations:

Volume $\%$ in entity

12. USFWS Wilderness Areas (FWSW)

Oil in Oil Accumulations:

Volume $\%$ in entity

Gas in Gas Accumulations:

Volume $\%$ in entity represents

2.48 area $\%$ of the $\mathrm{AU}$

minimum

mode

maximum

2.50
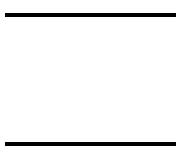
represents area $\%$ of the $\mathrm{AU}$

minimum

mode

maximum
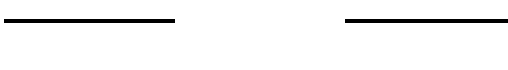

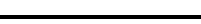
represents area $\%$ of the $\mathrm{AU}$

minimum

mode

maximum

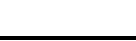

maximum
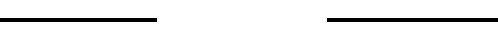

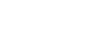

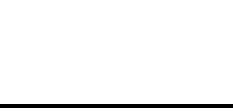

represents area $\%$ of the $\mathrm{AU}$

minimum

mode

maximum

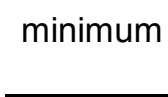
rep represents

0.44 area $\%$ of the $A U$

minimum

mode

0.50

maximum 
13. USFWS Protected Withdrawals (FWSP) represents area $\%$ of the $\mathrm{AU}$

Oil in Oil Accumulations:

minimum

mode

maximum

Volume $\%$ in entity

Gas in Gas Accumulations:

Volume \% in entity

14. Wilderness Study Areas (WS) represents area $\%$ of the $\mathrm{AU}$

Oil in Oil Accumulations:

minimum

Volume $\%$ in entity

Gas in Gas Accumulations:

Volume $\%$ in entity

15. Department of Energy (DOE) represents area $\%$ of the $\mathrm{AU}$

Oil in Oil Accumulations:

minimum

Volume \% in entity

mode

maximum

Gas in Gas Accumulations:

Volume \% in entity

16. Department of Defense (DOD) represents area $\%$ of the $\mathrm{AU}$

Oil in Oil Accumulations:

minimum

.
s maximum

Volume $\%$ in entity

mode

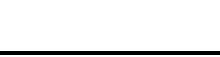

Gas in Gas Accumulations:

Volume $\%$ in entity

17. Bureau of Reclamation (BOR) represents area $\%$ of the $\mathrm{AU}$

Oil in Oil Accumulations:

minimum

mode

maximum

Volume $\%$ in entity

Gas in Gas Accumulations:

Volume $\%$ in entity

18. Tennessee Valley Authority (TVA) represents area $\%$ of the $\mathrm{AU}$

Oil in Oil Accumulations:

minimum

mode

maximum

Gas in Gas Accumulations:

Volume $\%$ in entity 
19. Other Federal

Oil in Oil Accumulations:

Volume $\%$ in entity

Gas in Gas Accumulations:

Volume $\%$ in entity

20.

Oil in Oil Accumulations:

Volume $\%$ in entity

Gas in Gas Accumulations:

Volume \% in entity represents

0.37 area $\%$ of the $\mathrm{AU}$

minimum

mode maximum

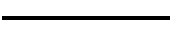

0.00

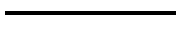
represents area $\%$ of the $\mathrm{AU}$

minimum

mode

maximum
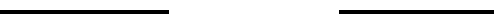

maximum




\section{ALLOCATIONS OF POTENTIAL ADDITIONS TO RESERVES TO ECOSYSTEMS Surface Allocations (uncertainty of a fixed value)}

1. Northeastern Glaciated Plains (NEGP) represents

9.14 area $\%$ of the $\mathrm{AU}$

Oil in Oil Accumulations:

Volume \% in entity

$\overline{-10}$

Gas in Gas Accumulations:

Volume $\%$ in entity

2. Northern Glaciated Plains (NGPL)

Oil in Oil Accumulations:

Volume $\%$ in entity

Gas in Gas Accumulations:

Volume $\%$ in entity

3. Northwestern Glaciated Plains (NWGL)

Oil in Oil Accumulations:

Volume $\%$ in entity

Gas in Gas Accumulations:

Volume $\%$ in entity

4. Northwestern Great Plains (NWGP)

Oil in Oil Accumulations:

Volume $\%$ in entity

Gas in Gas Accumulations:

Volume $\%$ in entity

5. Powder River Basin (PRBA)

Oil in Oil Accumulations:

Volume \% in entity

Gas in Gas Accumulations:

Volume $\%$ in entity

6.

Oil in Oil Accumulations:

Volume \% in entity

Gas in Gas Accumulations:

Volume $\%$ in entity

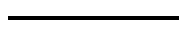

minimum

mode maximum

9.00

represents 8.27 area $\%$ of the $\mathrm{AU}$

minimum

mode

maximum

8.00

8.00

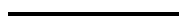
represents

5.12 area $\%$ of the $\mathrm{AU}$

minimum

mode

maximum

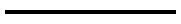

$$
5.00
$$

represents 69.35 area \% of the AU

minimum

mode

maximum

70.00
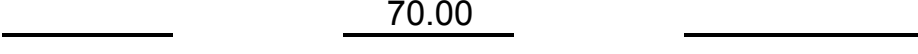

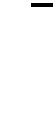
represents

8.11
area \% of the AU

minimum

mode 8.00

maximum represents area $\%$ of the $\mathrm{AU}$

minimum

mode maximum 
Table 3. Input parameters for the Elm Coulee-Billings Nose Continuous Oil Assessment Unit (50310161), Bakken Total Petroleum System, Williston Basin Province. [bcfg, billion cubic feet of gas; mmcfg, million cubic feet of gas; cfg, cubic feet of gas; mmbo, million barrels of oil; bo, barrel of oil; bliq, barrel of liquid; bngl, barrel of natural gas liquids; m, meters; AU, assessment unit; EUR, estimated ultimate recovery]

\section{INPUT DATA FORM FOR CONTINUOUS ACCUMULATIONS \\ (version 1.2, July 20, 2012)}

\section{IDENTIFICATION INFORMATION}

Assessment Geologist:

Region:

Province:

Total Petroleum System:

Assessment Unit:

Based on Data as of:

Notes from Assessor:
S. Gaswirth

North America

Williston Basin

Bakken

Elm Coulee-Billings Nose Continuous Oil

IHS Energy Group (2012), NRG Associates (2010)
Date: 29-Jan-13

Number: 5

Number: 5031

Number: 503101

Number: 50310161

Ancillary data from Pollastro (2008)

\section{CHARACTERISTICS OF ASSESSMENT UNIT}

Assessment-unit type: $\quad$ oil $(<20,000 \mathrm{cfg} / \mathrm{bo}) \frac{\mathrm{X}}{\text { heavy oil }(<10 \mathrm{API})}$ gas $(>20,000 \mathrm{cfg} / \mathrm{bo})$

Well type:

Major reservoir type (Choose one.):

vertical

horizontal $\mathrm{X}$

shale
coal

low-permeability clastics low-permeability carbonates diatomite

\begin{tabular}{lc} 
Minimum EUR per well & 0.002 \\
Number of tested wells: & $\frac{1132}{\text { Numbo for oil AU; bcfg for gas AU) }}$ \\
Number of tested wells with EUR > minimum: & \\
Historic success ratio, tested wells (\%) & $\frac{1120}{99}$ \\
\hline
\end{tabular}

Assessment-Unit Probability:

What is the probability that at least one well within the AU will have production capacity of at least the minimum EUR?

\section{NUMBER OF UNDRILLED WELLS WITH POTENTIAL FOR ADDITIONS TO RESERVES}

1. Productive area of accumulation (acres): (triangular)

calculated mean $1,600,000$ minimum $1,400,000$ mode $1,600,000$ maximum $1,800,000$

2. Uncertainty about average drainage area of wells (acres): (triangular)

calculated mean 440 minimum 320 mode 400 maximum 600

3. Percentage of total assessment-unit area that is untested (\%): (triangular) calculated mean 67 minimum $51 \quad$ mode 69 maximum 80

4. Percentage of untested assessment-unit area in sweet spots (\%): (triangular) calculated mean 27 minimum 24 mode 27 maximum 30 


\section{ESTIMATED ULTIMATE RECOVERY (EUR) PER WELL}

\section{SWEET SPOTS}

5a. Future success ratio (\%): (triangular) calculated mean 99 minimum 98 mode 99 maximum 100

5b. Uncertainty about average EUR (mmbo for oil; bcfg for gas): (shifted truncated lognormal)

calculated mean 0.182 minimum 0.15 median 0.18 maximum 0.22

\section{NON-SWEET SPOTS}

6a. Future success ratio (\%): (triangular)

$$
\text { calculated mean }
$$

90 minimum 85 mode 90 maximum 95

6b. Uncertainty about average EUR (mmbo for oil; bcfg for gas): (shifted truncated lognormal)

calculated mean 0.102 minimum 0.06 median 0.1 maximum 0.15

\section{UNCERTAINTY ABOUT AVERAGE COPRODUCT RATIOS FOR UNTESTED WELLS} (triangular)

Oil assessment unit: Gas/oil ratio (cfg/bo) $\mathrm{NGL} /$ gas ratio (bngl/mmcfg)

Gas assessment unit: Liquids/gas ratio (bliq/mmcfg)
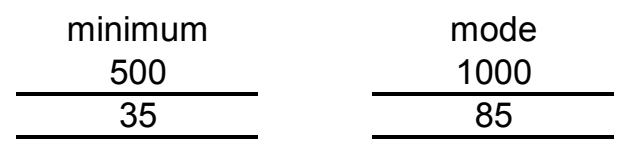


\section{SELECTED ANCILLARY DATA FOR UNTESTED WELLS}

(no specified distribution type)

Oil assessment unit:

API gravity of oil (degrees)

Sulfur content of oil (\%)

Depth $(m)$ of water (if applicable)

Drilling depth $(m)$

Gas assessment unit:

Inert-gas content (\%)

$\mathrm{CO}_{2}$ content $(\%)$

Hydrogen sulfide content (\%)

Heating value (BTU)

Depth $(m)$ of water (if applicable)

Drilling depth $(\mathrm{m})$

\begin{tabular}{|c|c|c|c|c|}
\hline $\begin{array}{c}\text { minimum } \\
34 \\
\end{array}$ & & $\begin{array}{c}\text { median } \\
41 \\
\end{array}$ & & $\begin{array}{c}\text { maximum } \\
50 \\
\end{array}$ \\
\hline 0.01 & & 0.1 & & 1 \\
\hline $\begin{array}{c}\text { minimum } \\
2130\end{array}$ & F75 & $\begin{array}{c}\text { median } \\
2895\end{array}$ & F25 & $\begin{array}{c}\text { maximum } \\
3200\end{array}$ \\
\hline
\end{tabular}

\begin{tabular}{|c|c|c|c|c|}
\hline minimum & & median & & maximum \\
\hline & & & & 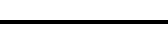 \\
\hline & & & & \\
\hline minimum & F75 & median & F25 & maximum \\
\hline
\end{tabular}

Completion practices:

1. Typical well-completion practices (conventional, open hole, open cavity, other)

2. Fraction of wells drilled that are typically stimulated

3. Predominant type of stimulation (none, frac, acid, other)

4. Historic fraction of wells drilled that are horizontal

\begin{tabular}{c}
$\frac{\text { open hole }}{1}$ \\
\hline frac \\
\hline 0.9
\end{tabular}




\section{ALLOCATIONS OF POTENTIAL ADDITIONS TO RESERVES TO STATES Surface Allocations (uncertainty of a fixed value)}

1. Montana

mean VOLUME \% in entity

2. North Dakota

mean VOLUME \% in entity

48.00

3.

mean VOLUME \% in entity

4.

mean VOLUME \% in entity

5.

mean VOLUME \% in entity

6.

mean VOLUME \% in entity

7.

mean VOLUME \% in entity

8.

mean VOLUME \% in entity

9.

mean VOLUME \% in entity

10.

mean VOLUME \% in entity

52.00 is

$52.10 \%$ of the AREA of the AU

is

$47.90 \%$ of the AREA of the AU

is $\%$ of the AREA of the AU

is $\%$ of the AREA of the AU

is $\%$ of the AREA of the AU

is $\%$ of the AREA of the AU

is $\%$ of the AREA of the AU

is $\%$ of the AREA of the AU

is $\%$ of the AREA of the AU

is $\%$ of the AREA of the AU 


\section{ALLOCATIONS OF POTENTIAL ADDITIONS TO RESERVES TO GENERAL LAND OWNERSHIPS Surface Allocations (uncertainty of a fixed value)}

1. Federal Lands

mean VOLUME \% in entity

2. Private Lands

mean VOLUME \% in entity

64.00

3. Tribal Lands

mean VOLUME \% in entity

4. Other Lands

mean VOLUME \% in entity

0.50

5. MT State Lands

mean VOLUME \% in entity

2.50

6. ND State Lands

mean VOLUME \% in entity

3.00

7.

mean VOLUME \% in entity

8.

mean VOLUME \% in entity

9.

mean VOLUME \% in entity

10.

mean VOLUME \% in entity is

$29.66 \%$ of the AREA of the AU

is

$63.93 \%$ of the AREA of the AU

is $\%$ of the AREA of the AU

is 0.7 [ $\%$ of the AREA of the AU

is $2.75 \%$ of the AREA of the AU $2.96 \%$ of the AREA of the AU $\%$ of the AREA of the AU $\%$ of the AREA of the AU $\%$ of the AREA of the AU

is $\%$ of the AREA of the AU 


\section{ALLOCATIONS OF POTENTIAL ADDITIONS TO RESERVES TO FEDERAL LAND SUBDIVISIONS Surface Allocations (uncertainty of a fixed value)}

1. Bureau of Land Management (BLM)

mean VOLUME \% in entity

1.00

2. BLM Wilderness Areas (BLMW)

mean VOLUME \% in entity

3. BLM Roadless Areas (BLMR)

mean VOLUME \% in entity

4. National Park Service (NPS)

mean VOLUME \% in entity

2.00

5. NPS Wilderness Areas (NPSW) mean VOLUME \% in entity

6. NPS Protected Withdrawals (NPSP) mean VOLUME \% in entity

7. US Forest Service (FS) mean VOLUME \% in entity 27.00

8. USFS Wilderness Areas (FSW) mean VOLUME \% in entity

9. USFS Roadless Areas (FSR) mean VOLUME \% in entity

10. USFS Protected Withdrawals (FSP) mean VOLUME \% in entity is

is

$1.10 \%$ of the AREA of the AU

is $\%$ of the AREA of the AU

is $\%$ of the AREA of the AU

is $1.66 \%$ of the AREA of the AU $\%$ of the AREA of the AU $26.85 \%$ of the AREA of the AU $\%$ of the AREA of the AU $\%$ of the AREA of the AU

is $\%$ of the AREA of the AU 


\section{ALLOCATIONS OF POTENTIAL ADDITIONS TO RESERVES TO FEDERAL LAND SUBDIVISIONS} (continued)

11. US Fish and Wildlife Service (FWS) mean VOLUME \% in entity

12. USFWS Wilderness Areas (FWSW) mean VOLUME \% in entity

13. USFWS Protected Withdrawals (FWSP) mean VOLUME \% in entity

14. Wilderness Study Areas (WS) mean VOLUME \% in entity

15. Department of Energy (DOE) mean VOLUME \% in entity

16. Department of Defense (DOD) mean VOLUME \% in entity

17. Bureau of Reclamation (BOR) mean VOLUME \% in entity

18. Tennessee Valley Authority (TVA) mean VOLUME \% in entity

19. Other Federal mean VOLUME \% in entity 0.00

20. mean VOLUME \% in entity is $\%$ of the AREA of the AU

is $\%$ of the AREA of the AU

is $\%$ of the AREA of the AU

is $\%$ of the AREA of the AU

is $\%$ of the AREA of the AU $\%$ of the AREA of the AU $\%$ of the AREA of the AU $\%$ of the AREA of the AU $0.00 \%$ of the AREA of the AU is $\%$ of the AREA of the AU 


\section{ALLOCATIONS OF POTENTIAL ADDITIONS TO RESERVES TO ECOSYSTEMS \\ Surface Allocations (uncertainty of a fixed value)}

1. Northern Glaciated Plains (NGPL) mean VOLUME \% in entity 29.00

2. Northwestern Glaciated Plains (NWGL) mean VOLUME \% in entity 1.00

3. Northwestern Great Plains (NWGP) mean VOLUME \% in entity 70.00

4. mean VOLUME \% in entity

5. mean VOLUME \% in entity

6. mean VOLUME \% in entity

7. mean VOLUME \% in entity

8. mean VOLUME \% in entity

9. mean VOLUME \% in entity

10. mean VOLUME \% in entity is $29.40 \%$ of the AREA of the AU

is $0.73 \%$ of the AREA of the AU

is $69.87 \%$ of the AREA of the AU

is $\%$ of the AREA of the AU $\%$ of the AREA of the AU $\%$ of the AREA of the AU $\%$ of the AREA of the AU $\%$ of the AREA of the AU $\%$ of the AREA of the AU

is $\%$ of the AREA of the AU 
Table 4. Input parameters for the Central Basin Continuous Oil Assessment Unit (50310162), Bakken Total Petroleum System, Williston Basin Province. [bcfg, billion cubic feet of gas; mmcfg, million cubic feet of gas; cfg, cubic feet of gas; mmbo, million barrels of oil; bo, barrel of oil; bliq, barrel of liquid; bngl, barrel of natural gas liquids; m, meters; AU, assessment unit; EUR, estimated ultimate recovery]

\section{INPUT DATA FORM FOR CONTINUOUS ACCUMULATIONS}

(version 1.2, July 20, 2012)

\section{IDENTIFICATION INFORMATION}

Assessment Geologist:

Region:

Province:

Total Petroleum System:

Assessment Unit:

Based on Data as of:

Notes from Assessor:
S. Gaswirth

North America

Williston Basin

Bakken

Central Basin Continuous Oil

IHS Energy Group (2012), NRG Associates (2010)
Date: $\quad 29-J a n-13$

Number: 5

Number: 5031

Number: 503101

Number: 50310162

\section{CHARACTERISTICS OF ASSESSMENT UNIT}

Assessment-unit type: $\quad$ oil $(<20,000 \mathrm{cfg} / \mathrm{bo}) \frac{X}{\text { heavy oil }(<10 \mathrm{API})}$ gas $(>20,000 \mathrm{cfg} / \mathrm{bo})$

Well type:

Major reservoir type (Choose one.): vertical horizontal shale
coal low-permeability clastics
low-permeability carbonates

Minimum EUR per well 0.002 (mmbo for oil AU; bcfg for gas AU)

Number of tested wells: 938 Number of tested wells with EUR > minimum: Historic success ratio, tested wells (\%)

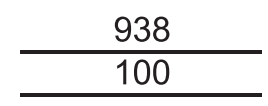

Assessment-Unit Probability:

What is the probability that at least one well within the AU will have production capacity of at least the minimum EUR?

\section{NUMBER OF UNDRILLED WELLS WITH POTENTIAL FOR ADDITIONS TO RESERVES}

1. Productive area of accumulation (acres): (triangular)

calculated mean $\quad 3,100,000$ minimum $\quad 2,800,000$ mode $3,100,000$ maximum $3,400,000$

2. Uncertainty about average drainage area of wells (acres): (triangular)

calculated mean 440 minimum 320 mode 400 maximum 600

3. Percentage of total assessment-unit area that is untested (\%): (triangular) calculated mean 86 minimum 80 mode 87 maximum

4. Percentage of untested assessment-unit area in sweet spots (\%): (triangular) calculated mean 41 minimum 24 mode 29 maximum 70 


\section{ESTIMATED ULTIMATE RECOVERY (EUR) PER WELL \\ SWEET SPOTS}

5a. Future success ratio (\%): (triangular)

calculated mean

99

minimum

98

mode

99

maximum

100

5b. Uncertainty about average EUR (mmbo for oil; bcfg for gas): (shifted truncated lognormal)

calculated mean

0.254

minimum

0.225 median

0.25

maximum

0.325

\section{NON-SWEET SPOTS}

6a. Future success ratio (\%): (triangular)

calculated mean

88

minimum

80

mode

90

maximum

95

6b. Uncertainty about average EUR (mmbo for oil; bcfg for gas): (shifted truncated lognormal)

calculated mean

0.154

minimum

0.075 median

0.15 maximum

0.25

\section{UNCERTAINTY ABOUT AVERAGE COPRODUCT RATIOS FOR UNTESTED WELLS}

(triangular)

Oil assessment unit:

Gas/oil ratio (cfg/bo)

$\mathrm{NGL} / \mathrm{gas}$ ratio (bngl/mmcfg)
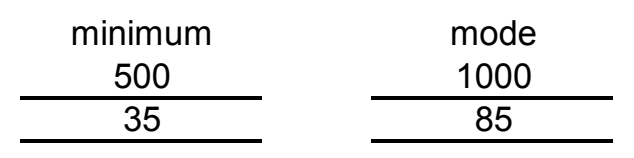

\begin{tabular}{c}
$\begin{array}{c}\text { maximum } \\
1500\end{array}$ \\
\hline 115 \\
\hline
\end{tabular}

Gas assessment unit:

Liquids/gas ratio (bliq/mmcfg) 


\section{SELECTED ANCILLARY DATA FOR UNTESTED WELLS}

(no specified distribution type)

Oil assessment unit:

API gravity of oil (degrees)

Sulfur content of oil (\%)

Depth $(\mathrm{m})$ of water (if applicable)

Drilling depth $(m)$

Gas assessment unit:

Inert-gas content (\%)

$\mathrm{CO}_{2}$ content $(\%)$

Hydrogen sulfide content (\%)

Heating value (BTU)

Depth $(m)$ of water (if applicable)

Drilling depth $(\mathrm{m})$

\begin{tabular}{|c|c|c|c|c|}
\hline $\begin{array}{l}\text { minimum } \\
34\end{array}$ & & $\begin{array}{c}\text { median } \\
41\end{array}$ & & $\begin{array}{c}\text { maximum } \\
50\end{array}$ \\
\hline 0.01 & & 0.1 & & 1 \\
\hline $\begin{array}{c}\text { minimum } \\
2130\end{array}$ & F75 & $\begin{array}{c}\text { median } \\
2895\end{array}$ & F25 & $\begin{array}{c}\text { maximum } \\
3200\end{array}$ \\
\hline
\end{tabular}

minimum

median

maximum

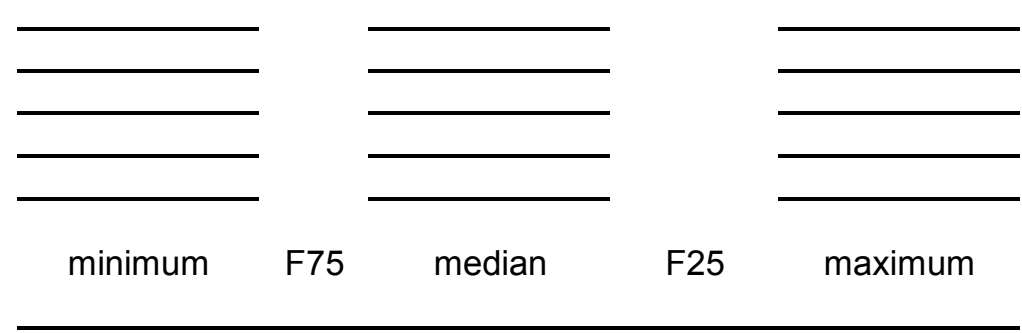

Completion practices:

1. Typical well-completion practices (conventional, open hole, open cavity, other)

2. Fraction of wells drilled that are typically stimulated

3. Predominant type of stimulation (none, frac, acid, other)

4. Historic fraction of wells drilled that are horizontal

\begin{tabular}{c}
$\frac{\text { open hole }}{1}$ \\
\hline frac \\
\hline 0.996 \\
\hline
\end{tabular}




\section{ALLOCATIONS OF POTENTIAL ADDITIONS TO RESERVES TO STATES \\ Surface Allocations (uncertainty of a fixed value)}

1. Montana

mean VOLUME \% in entity

2. North Dakota

mean VOLUME \% in entity

70.00

3.

mean VOLUME \% in entity

4.

mean VOLUME \% in entity

5.

mean VOLUME \% in entity

6.

mean VOLUME \% in entity

7.

mean VOLUME \% in entity

8.

mean VOLUME \% in entity

9.

mean VOLUME \% in entity

10.

mean VOLUME \% in entity is

$47.95 \%$ of the AREA of the AU is

$52.05 \%$ of the AREA of the AU

is $\%$ of the AREA of the AU

is $\%$ of the AREA of the AU

is $\%$ of the AREA of the AU

is $\%$ of the AREA of the AU

is $\%$ of the AREA of the AU

is $\%$ of the AREA of the AU

is $\%$ of the AREA of the AU

is $\%$ of the AREA of the AU 


\section{ALLOCATIONS OF POTENTIAL ADDITIONS TO RESERVES TO GENERAL LAND OWNERSHIPS Surface Allocations (uncertainty of a fixed value)}

1. Federal Lands

mean VOLUME \% in entity

2. Private Lands

mean VOLUME \% in entity

70.00

3. Tribal Lands

mean VOLUME \% in entity

15.00

4. Other Lands

mean VOLUME \% in entity

2.00

5. MT State Lands

mean VOLUME \% in entity

1.00

6. ND State Lands

mean VOLUME \% in entity

2.00

7.

mean VOLUME \% in entity

8.

mean VOLUME \% in entity

9.

mean VOLUME \% in entity

10.

mean VOLUME \% in entity is

$8.87 \%$ of the AREA of the AU

is

$63.08 \%$ of the AREA of the AU

is

$23.30 \%$ of the AREA of the AU

is

$1.47 \%$ of the AREA of the AU

is

$1.35 \%$ of the AREA of the AU

is

$1.93 \%$ of the AREA of the AU

is $\%$ of the AREA of the AU

is $\%$ of the AREA of the AU

is $\%$ of the AREA of the AU

is $\%$ of the AREA of the AU 


\section{ALLOCATIONS OF POTENTIAL ADDITIONS TO RESERVES TO FEDERAL LAND SUBDIVISIONS Surface Allocations (uncertainty of a fixed value)}

1. Bureau of Land Management (BLM) mean VOLUME \% in entity 1.00

2. BLM Wilderness Areas (BLMW) mean VOLUME \% in entity

\section{BLM Roadless Areas (BLMR)} mean VOLUME \% in entity

4. National Park Service (NPS) mean VOLUME \% in entity 1.00 is

$1.22 \%$ of the AREA of the AU

is $\%$ of the AREA of the AU

is $\%$ of the AREA of the AU $0.68 \%$ of the AREA of the AU

5. NPS Wilderness Areas (NPSW) $\%$ of the AREA of the AU mean VOLUME \% in entity

6. NPS Protected Withdrawals (NPSP) $\%$ of the AREA of the AU mean VOLUME \% in entity

7. US Forest Service (FS) $4.49 \%$ of the AREA of the AU mean VOLUME \% in entity 5.00

8. USFS Wilderness Areas (FSW) $\%$ of the AREA of the AU mean VOLUME \% in entity

9. USFS Roadless Areas (FSR) $\%$ of the AREA of the AU mean VOLUME \% in entity

10. USFS Protected Withdrawals (FSP) is $\%$ of the AREA of the AU mean VOLUME \% in entity 


\section{ALLOCATIONS OF POTENTIAL ADDITIONS TO RESERVES TO FEDERAL LAND SUBDIVISIONS} (continued)

11. US Fish and Wildlife Service (FWS) mean VOLUME \% in entity 1.00
12. USFWS Wilderness Areas (FWSW) mean VOLUME \% in entity

13. USFWS Protected Withdrawals (FWSP) mean VOLUME \% in entity

14. Wilderness Study Areas (WS) mean VOLUME \% in entity

15. Department of Energy (DOE) mean VOLUME \% in entity

16. Department of Defense (DOD) mean VOLUME \% in entity

17. Bureau of Reclamation (BOR) mean VOLUME \% in entity

18. Tennessee Valley Authority (TVA) mean VOLUME \% in entity

19. Other Federal mean VOLUME \% in entity 2.00

20. mean VOLUME \% in entity is $0.46 \%$ of the AREA of the AU

is $\%$ of the AREA of the AU

is $\%$ of the AREA of the AU $\%$ of the AREA of the AU $\%$ of the AREA of the AU $\%$ of the AREA of the AU $\%$ of the AREA of the AU $2.02 \%$ of the AREA of the AU is $\%$ of the AREA of the AU 


\section{ALLOCATIONS OF POTENTIAL ADDITIONS TO RESERVES TO ECOSYSTEMS Surface Allocations (uncertainty of a fixed value)}

1. Northern Glaciated Plains (NGPL) mean VOLUME \% in entity 77.00

2. Northwestern Glaciated Plains (NWGL) mean VOLUME \% in entity 6.00

3. Northwestern Great Plains (NWGP) mean VOLUME \% in entity 17.00

4. mean VOLUME \% in entity

5. mean VOLUME \% in entity

6. mean VOLUME \% in entity

7. mean VOLUME \% in entity

8. mean VOLUME \% in entity

9. mean VOLUME \% in entity

10. mean VOLUME \% in entity is 77.18 $\%$ of the AREA of the AU

is $6.23 \%$ of the AREA of the AU $16.59 \%$ of the AREA of the AU

is $\%$ of the AREA of the AU $\%$ of the AREA of the AU $\%$ of the AREA of the AU $\%$ of the AREA of the AU $\%$ of the AREA of the AU $\%$ of the AREA of the AU is $\%$ of the AREA of the AU 
Table 5. Input parameters for the Nesson-Little Knife Continuous Oil Assessment Unit (50310163), Bakken Total Petroleum System, Williston Basin Province. [bcfg, billion cubic feet of gas; mmcfg, million cubic feet of gas; cfg, cubic feet of gas; mmbo, million barrels of oil; bo, barrel of oil; bliq, barrel of liquid; bngl, barrel of natural gas liquids; m, meters; AU, assessment unit; EUR, estimated ultimate recovery]

\section{INPUT DATA FORM FOR CONTINUOUS ACCUMULATIONS}

(version 1.2, July 20, 2012)

\section{IDENTIFICATION INFORMATION}

Assessment Geologist:

Region:

Province:

Total Petroleum System:

Assessment Unit:

Based on Data as of:

Notes from Assessor:
S. Gaswirth

North America

Williston Basin

Bakken

Nesson-Little Knife Continuous Oil

IHS Energy Group (2012), NRG Associates (2010)
Date:

Number:

Number:

Number:

Number:

$\frac{\frac{29-J a n-13}{5}}{\frac{5031}{503101}}$

\section{Ancillary data from Pollastro (2008)}

\section{CHARACTERISTICS OF ASSESSMENT UNIT}

Assessment-unit type:

Well type:

Major reservoir type (Choose one.):

shale

coal oil $(<20,000 \mathrm{cfg} / \mathrm{bo}) \frac{X}{\text { heavy oil }(<10 \mathrm{API})}$ gas $(>20,000 \mathrm{cfg} / \mathrm{bo})$ vertical horizontal

coal $\quad \begin{array}{r}\text { low-permeability clastics } \\ \text { low-permeability carbonates } \\ \text { diatomite }\end{array}$

\section{Minimum EUR per well $\quad 0.002$ (mmbo for oil AU; bcfg for gas AU) \\ Number of tested wells: \\ 1554}

Number of tested wells with EUR > minimum:

Historic success ratio, tested wells (\%)

$\frac{1554}{100}$

\section{Assessment-Unit Probability:}

What is the probability that at least one well within the AU will have production capacity of at least the minimum EUR?

\section{NUMBER OF UNDRILLED WELLS WITH POTENTIAL FOR ADDITIONS TO RESERVES}

1. Productive area of accumulation (acres): (triangular)

calculated mean $2,800,000$ minimum $2,600,000$ mode $2,800,000$ maximum $3,000,000$

2. Uncertainty about average drainage area of wells (acres): (triangular)

calculated mean

440 minimum 320 mode 400 maximum 600

3. Percentage of total assessment-unit area that is untested (\%): (triangular)

calculated mean 75 minimum 65 mode 76 maximum 84

4. Percentage of untested assessment-unit area in sweet spots (\%): (triangular)

calculated mean 53 minimum 35 mode 38 maximum 85 


\section{ESTIMATED ULTIMATE RECOVERY (EUR) PER WELL}

\section{SWEET SPOTS}

5a. Future success ratio (\%): (triangular)

calculated mean

99

minimum

98

mode

99

maximum

100

5b. Uncertainty about average EUR (mmbo for oil; bcfg for gas): (shifted truncated lognormal)

calculated mean

0.302

minimum

0.26

median

0.3

maximum

0.35

\section{NON-SWEET SPOTS}

6a. Future success ratio (\%): (triangular)

calculated mean

95

minimum

90

mode

95

maximum

100

6b. Uncertainty about average EUR (mmbo for oil; bcfg for gas): (shifted truncated lognormal)

calculated mean

0.178

minimum

0.125

median

0.175

maximum

0.25

\section{UNCERTAINTY ABOUT AVERAGE COPRODUCT RATIOS FOR UNTESTED WELLS}

(triangular)

Oil assessment unit:

Gas/oil ratio (cfg/bo)

NGL/gas ratio (bngl/mmcfg)
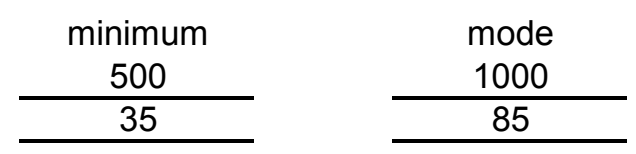

\begin{tabular}{c}
$\begin{array}{c}\text { maximum } \\
1500\end{array}$ \\
\hline 115 \\
\hline
\end{tabular}

Gas assessment unit:

Liquids/gas ratio (bliq/mmcfg)

Page 2 


\section{SELECTED ANCILLARY DATA FOR UNTESTED WELLS}

(no specified distribution type)

Oil assessment unit:

API gravity of oil (degrees)

Sulfur content of oil (\%)

Depth $(m)$ of water (if applicable)

Drilling depth $(m)$

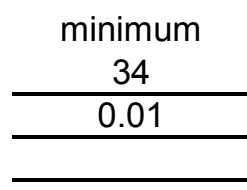

minimum

2130

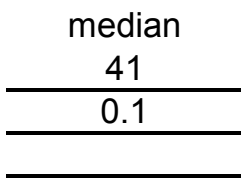

F75

median maximum

50

1

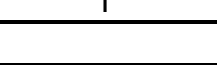

F25

maximum

Gas assessment unit: Inert-gas content (\%)

$\mathrm{CO}_{2}$ content (\%)

Hydrogen sulfide content (\%)

Heating value (BTU)

Depth $(m)$ of water (if applicable)

Drilling depth $(m)$

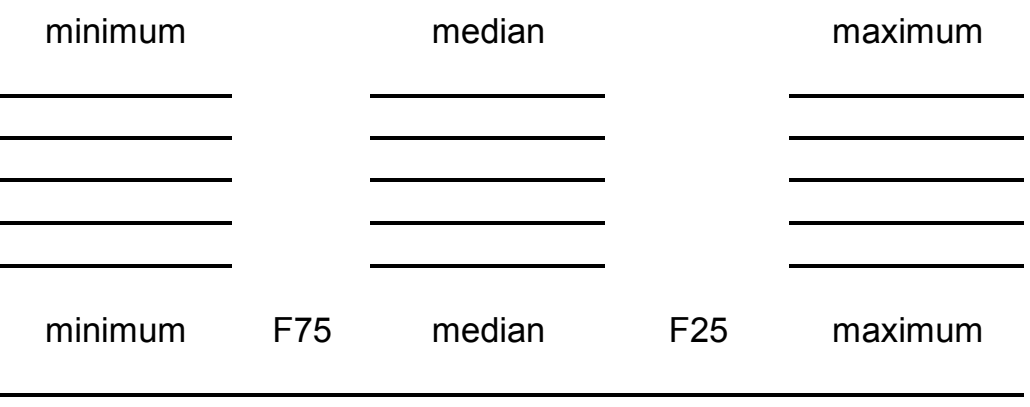

Completion practices:

1. Typical well-completion practices (conventional, open hole, open cavity, other)

2. Fraction of wells drilled that are typically stimulated

3. Predominant type of stimulation (none, frac, acid, other)

4. Historic fraction of wells drilled that are horizontal

\begin{tabular}{c}
$\frac{\text { open hole }}{1}$ \\
\hline frac \\
\hline 0.95 \\
\hline
\end{tabular}

Page 3 


\section{ALLOCATIONS OF POTENTIAL ADDITIONS TO RESERVES TO STATES \\ Surface Allocations (uncertainty of a fixed value)}

1. North Dakota

mean VOLUME \% in entity

2.

mean VOLUME \% in entity

3.

mean VOLUME \% in entity

4.

mean VOLUME \% in entity

5.

mean VOLUME \% in entity

6.

mean VOLUME \% in entity

7.

mean VOLUME \% in entity

8.

mean VOLUME \% in entity

9.

mean VOLUME \% in entity

10.

mean VOLUME \% in entity is $\quad 100.00 \%$ of the AREA of the AU

100.00

is $\%$ of the AREA of the AU

is $\%$ of the AREA of the AU

is $\%$ of the AREA of the AU

is $\%$ of the AREA of the AU

is $\%$ of the AREA of the AU

is $\%$ of the AREA of the AU

is $\%$ of the AREA of the AU

is $\%$ of the AREA of the AU

is $\%$ of the AREA of the AU 


\section{ALLOCATIONS OF POTENTIAL ADDITIONS TO RESERVES TO GENERAL LAND OWNERSHIPS Surface Allocations (uncertainty of a fixed value)}

1. Federal Lands

mean VOLUME \% in entity

2. Private Lands

mean VOLUME \% in entity

79.00

3. Tribal Lands

mean VOLUME \% in entity

9.00

4. Other Lands

mean VOLUME \% in entity

1.00

5. ND State Lands

mean VOLUME \% in entity

4.00

6.

mean VOLUME \% in entity

7.

mean VOLUME \% in entity

8.

mean VOLUME \% in entity

9.

mean VOLUME \% in entity

10.

mean VOLUME \% in entity is $\quad 6.84 \%$ of the AREA of the AU

is $\quad 79.03 \%$ of the AREA of the AU

is $\quad 9.08 \%$ of the AREA of the AU

is $\quad 0.8 \square \%$ of the AREA of the AU

is

$4.21 \%$ of the AREA of the AU

is $\%$ of the AREA of the AU

is $\%$ of the AREA of the AU

is $\%$ of the AREA of the AU

is $\%$ of the AREA of the AU

is $\%$ of the AREA of the AU 


\section{ALLOCATIONS OF POTENTIAL ADDITIONS TO RESERVES TO FEDERAL LAND SUBDIVISIONS Surface Allocations (uncertainty of a fixed value)}

1. Bureau of Land Management (BLM) mean VOLUME \% in entity 0.50

2. BLM Wilderness Areas (BLMW) mean VOLUME \% in entity

3. BLM Roadless Areas (BLMR) mean VOLUME \% in entity

4. National Park Service (NPS) mean VOLUME \% in entity 0.00

5. NPS Wilderness Areas (NPSW) mean VOLUME \% in entity

6. NPS Protected Withdrawals (NPSP) mean VOLUME \% in entity

7. US Forest Service (FS) mean VOLUME \% in entity 3.00

8. USFS Wilderness Areas (FSW) mean VOLUME \% in entity

9. USFS Roadless Areas (FSR) mean VOLUME \% in entity

10. USFS Protected Withdrawals (FSP) mean VOLUME \% in entity is

$0.45 \%$ of the AREA of the AU

is $\%$ of the AREA of the AU

is $\%$ of the AREA of the AU

is $0.08 \%$ of the AREA of the AU

is $\%$ of the AREA of the AU

is $\%$ of the AREA of the AU

is $2.67 \%$ of the AREA of the AU is $\%$ of the AREA of the AU

is $\%$ of the AREA of the AU

is $\%$ of the AREA of the AU 


\section{ALLOCATIONS OF POTENTIAL ADDITIONS TO RESERVES TO FEDERAL LAND SUBDIVISIONS} (continued)

11. US Fish and Wildlife Service (FWS) mean VOLUME \% in entity 0.50

12. USFWS Wilderness Areas (FWSW) mean VOLUME \% in entity

13. USFWS Protected Withdrawals (FWSP) mean VOLUME \% in entity

14. Wilderness Study Areas (WS) mean VOLUME \% in entity

15. Department of Energy (DOE) mean VOLUME \% in entity

16. Department of Defense (DOD) mean VOLUME \% in entity

17. Bureau of Reclamation (BOR) mean VOLUME \% in entity

18. Tennessee Valley Authority (TVA) mean VOLUME \% in entity

19. Other Federal mean VOLUME \% in entity 3.00

20. mean VOLUME \% in entity is $\quad 0.38 \%$ of the AREA of the AU

is $\%$ of the AREA of the AU

is $\%$ of the AREA of the AU

is $\%$ of the AREA of the AU

is $\%$ of the AREA of the AU

is $\%$ of the AREA of the AU

is $\%$ of the AREA of the AU

is $\%$ of the AREA of the AU

is $3.25 \%$ of the AREA of the AU is $\%$ of the AREA of the AU 


\section{ALLOCATIONS OF POTENTIAL ADDITIONS TO RESERVES TO ECOSYSTEMS Surface Allocations (uncertainty of a fixed value)}

1. Northeastern Glaciated Plains (NEGP) mean VOLUME \% in entity 7.00

2. Northern Glaciated Plains (NGPL) mean VOLUME \% in entity 46.00

3. Northwestern Great Plains (NWGP) mean VOLUME \% in entity 47.00

4. mean VOLUME \% in entity

5. mean VOLUME \% in entity

6. mean VOLUME \% in entity

7. mean VOLUME \% in entity

8. mean VOLUME \% in entity

9. mean VOLUME \% in entity

10. mean VOLUME \% in entity is $6.57 \%$ of the AREA of the AU

is $46.09 \%$ of the AREA of the AU

is $47.34 \%$ of the AREA of the AU

is $\%$ of the AREA of the AU

is $\%$ of the AREA of the AU

is $\%$ of the AREA of the AU

is $\%$ of the AREA of the AU

is $\%$ of the AREA of the AU

is $\%$ of the AREA of the AU

is $\%$ of the AREA of the AU 
Table 6. Input parameters for the Eastern Transitional Continuous Oil Assessment Unit (50310164), Bakken Total Petroleum System, Williston Basin Province. [bcfg, billion cubic feet of gas; mmcfg, million cubic feet of gas; cfg, cubic feet of gas; mmbo, million barrels of oil; bo, barrel of oil; bliq, barrel of liquid; bngl, barrel of natural gas liquids; m, meters; AU, assessment unit; EUR, estimated ultimate recovery]

\section{INPUT DATA FORM FOR CONTINUOUS ACCUMULATIONS}

(version 1.2, July 20, 2012)

\section{IDENTIFICATION INFORMATION}

\begin{tabular}{|c|c|c|c|}
\hline Assessment Geologist: & S. Gaswirth & Date: & 29-Jan-13 \\
\hline Region: & North America & Number: & 5 \\
\hline Province: & Williston Basin & Number: & 5031 \\
\hline Total Petroleum System: & Bakken & Number: & 503101 \\
\hline Assessment Unit: & Eastern Transitional Continuous Oil & Number: & 50310164 \\
\hline Based on Data as of: & IHS Energy Group (2012), NRG Associates (2010) & & \\
\hline Notes from Assessor: & Ancillary data from Pollastro (2008) & & \\
\hline
\end{tabular}

\section{CHARACTERISTICS OF ASSESSMENT UNIT}

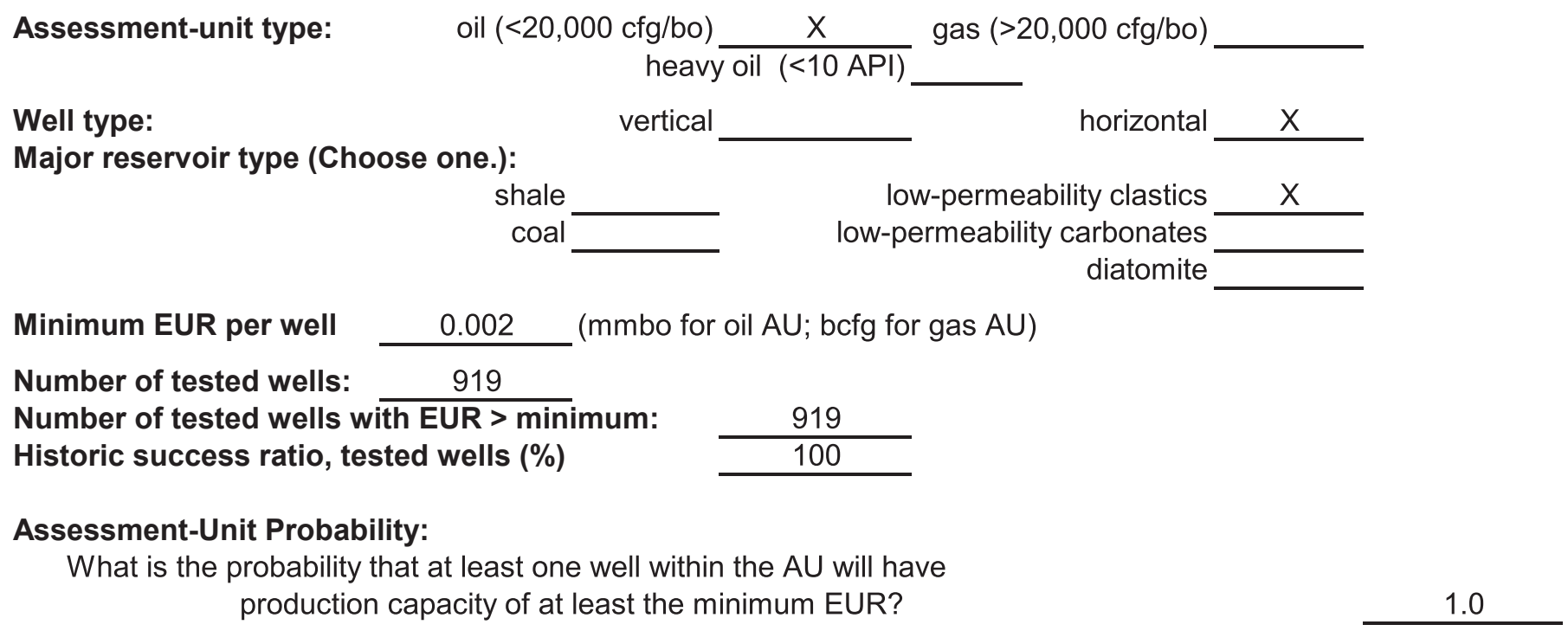

\section{NUMBER OF UNDRILLED WELLS WITH POTENTIAL FOR ADDITIONS TO RESERVES}

1. Productive area of accumulation (acres): (triangular)

calculated mean $1,900,000$ minimum $1,800,000$ mode $1,900,000$ maximum $2,000,000$

2. Uncertainty about average drainage area of wells (acres): (triangular)

calculated mean $\quad 440$ minimum $\quad 320 \quad$ mode $\_400 \quad$ maximum $\quad 600$

3. Percentage of total assessment-unit area that is untested (\%): (triangular)

calculated mean $\quad 81 \quad$ minimum $\quad 70 \quad$ mode $\_99 \quad$ maximum $\quad 93$

4. Percentage of untested assessment-unit area in sweet spots (\%): (triangular)

calculated mean $15 \quad$ minimum $\quad 10 \quad$ mode $\quad 15 \quad$ maximum 20




\section{ESTIMATED ULTIMATE RECOVERY (EUR) PER WELL}

\section{SWEET SPOTS}

5a. Future success ratio (\%): (triangular)

calculated mean 99 minimum

98

mode

99

maximum

100

5b. Uncertainty about average EUR (mmbo for oil; bcfg for gas): (shifted truncated lognormal)

calculated mean

0.431 minimum

0.375 median

0.425 maximum

0.55

\section{NON-SWEET SPOTS}

6a. Future success ratio (\%): (triangular)

calculated mean

95 minimum

90

mode 95 maximum 100

6b. Uncertainty about average EUR (mmbo for oil; bcfg for gas): (shifted truncated lognormal)

calculated mean 0.231 minimum 0.175 median 0.225 maximum 0.35

\section{UNCERTAINTY ABOUT AVERAGE COPRODUCT RATIOS FOR UNTESTED WELLS}

(triangular)

Oil assessment unit:

Gas/oil ratio (cfg/bo)

$\mathrm{NGL} / \mathrm{gas}$ ratio $(\mathrm{bngl} / \mathrm{mmcfg})$

Gas assessment unit:

Liquids/gas ratio (bliq/mmcfg)
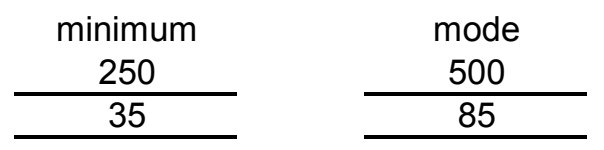

maximum 750

115 


\section{SELECTED ANCILLARY DATA FOR UNTESTED WELLS}

(no specified distribution type)

Oil assessment unit:

API gravity of oil (degrees)

Sulfur content of oil (\%)

Depth $(\mathrm{m})$ of water (if applicable)

Drilling depth $(m)$

Gas assessment unit:

Inert-gas content (\%)

$\mathrm{CO}_{2}$ content $(\%)$

Hydrogen sulfide content (\%)

Heating value (BTU)

Depth $(m)$ of water (if applicable)

Drilling depth $(\mathrm{m})$
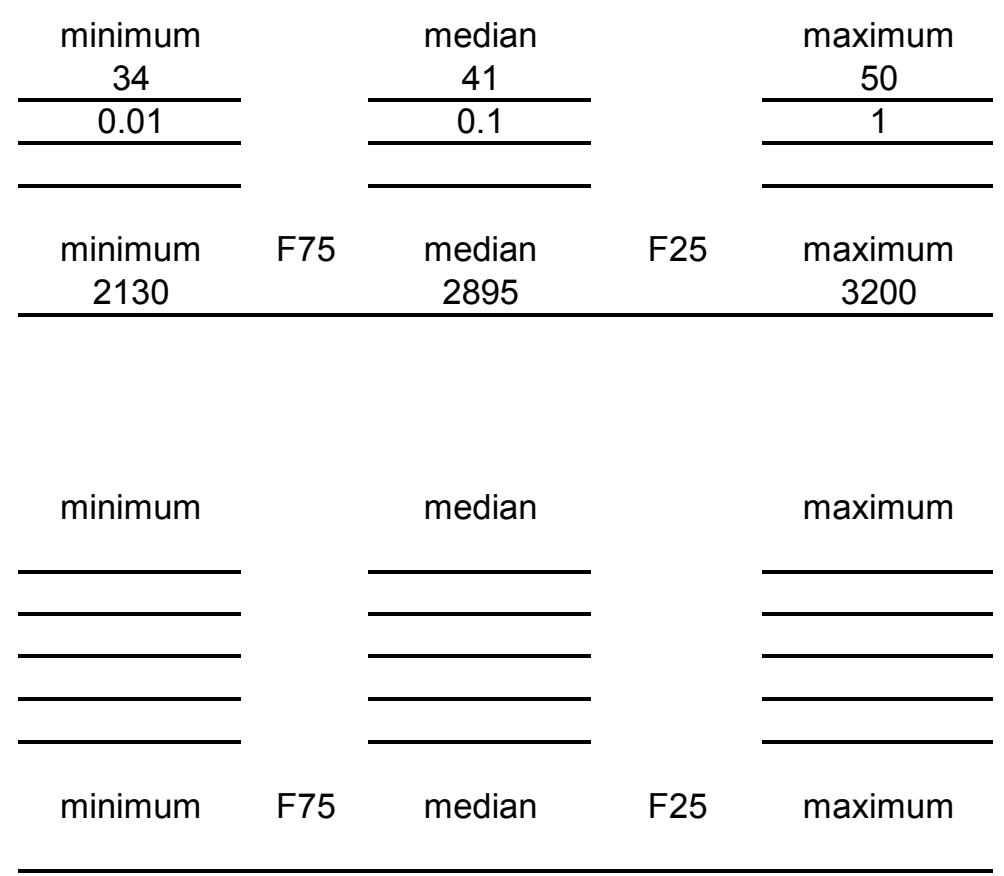

Completion practices:

1. Typical well-completion practices (conventional, open hole, open cavity, other)

2. Fraction of wells drilled that are typically stimulated

3. Predominant type of stimulation (none, frac, acid, other)

4. Historic fraction of wells drilled that are horizontal

\begin{tabular}{c}
$\frac{\text { open hole }}{1}$ \\
\hline frac \\
\hline 1 \\
\hline
\end{tabular}




\section{ALLOCATIONS OF POTENTIAL ADDITIONS TO RESERVES TO STATES \\ Surface Allocations (uncertainty of a fixed value)}

1. North Dakota

mean VOLUME \% in entity

2.

mean VOLUME \% in entity

3.

mean VOLUME \% in entity

4.

mean VOLUME \% in entity

5.

mean VOLUME \% in entity

6.

mean VOLUME \% in entity

7.

mean VOLUME \% in entity

8.

mean VOLUME \% in entity

9.

mean VOLUME \% in entity

10.

mean VOLUME \% in entity is $\quad 100.00 \%$ of the AREA of the AU

100.00

is $\%$ of the AREA of the AU

is $\%$ of the AREA of the AU

is $\%$ of the AREA of the AU

is $\%$ of the AREA of the AU

is $\%$ of the AREA of the AU

is $\%$ of the AREA of the AU

is $\%$ of the AREA of the AU

is $\%$ of the AREA of the AU

is $\%$ of the AREA of the AU 


\section{ALLOCATIONS OF POTENTIAL ADDITIONS TO RESERVES TO GENERAL LAND OWNERSHIPS Surface Allocations (uncertainty of a fixed value)}

1. Federal Lands

mean VOLUME \% in entity

2. Private Lands

mean VOLUME \% in entity

69.00

3. Tribal Lands

mean VOLUME \% in entity

18.00

4. Other Lands

mean VOLUME \% in entity

1.00

5. ND State Lands

mean VOLUME \% in entity

3.00

6.

mean VOLUME \% in entity

7.

mean VOLUME \% in entity

8.

mean VOLUME \% in entity

9.

mean VOLUME \% in entity

10.

mean VOLUME \% in entity

9.00 is

$8.71 \%$ of the AREA of the AU

is

$69.52 \%$ of the AREA of the AU

is

$17.74 \%$ of the AREA of the AU

is

$1.03 \%$ of the AREA of the AU

is

$3.01 \%$ of the AREA of the AU

is

$\%$ of the AREA of the AU

is

$\%$ of the AREA of the AU

is $\%$ of the AREA of the AU

is

$\%$ of the AREA of the AU

is $\%$ of the AREA of the AU 


\section{ALLOCATIONS OF POTENTIAL ADDITIONS TO RESERVES TO FEDERAL LAND SUBDIVISIONS Surface Allocations (uncertainty of a fixed value)}

1. Bureau of Land Management (BLM) mean VOLUME \% in entity 0.00

2. BLM Wilderness Areas (BLMW) mean VOLUME \% in entity

3. BLM Roadless Areas (BLMR) mean VOLUME \% in entity

4. National Park Service (NPS) mean VOLUME \% in entity

5. NPS Wilderness Areas (NPSW) mean VOLUME \% in entity

6. NPS Protected Withdrawals (NPSP) mean VOLUME \% in entity

7. US Forest Service (FS) mean VOLUME \% in entity

8. USFS Wilderness Areas (FSW) mean VOLUME \% in entity

9. USFS Roadless Areas (FSR) mean VOLUME \% in entity

10. USFS Protected Withdrawals (FSP) mean VOLUME \% in entity is $0.02 \%$ of the AREA of the AU

is $\%$ of the AREA of the AU

is $\%$ of the AREA of the AU

is $\%$ of the AREA of the AU

is $\%$ of the AREA of the AU

is $\%$ of the AREA of the AU

is $\%$ of the AREA of the AU

is $\%$ of the AREA of the AU

is $\%$ of the AREA of the AU

is $\%$ of the AREA of the AU 


\section{ALLOCATIONS OF POTENTIAL ADDITIONS TO RESERVES TO FEDERAL LAND SUBDIVISIONS} (continued)

11. US Fish and Wildlife Service (FWS) mean VOLUME \% in entity 2.00

12. USFWS Wilderness Areas (FWSW) mean VOLUME \% in entity

13. USFWS Protected Withdrawals (FWSP) mean VOLUME \% in entity

14. Wilderness Study Areas (WS) mean VOLUME \% in entity

15. Department of Energy (DOE) mean VOLUME \% in entity

16. Department of Defense (DOD) mean VOLUME \% in entity

17. Bureau of Reclamation (BOR) mean VOLUME \% in entity

18. Tennessee Valley Authority (TVA) mean VOLUME \% in entity

19. Other Federal mean VOLUME \% in entity 7.00

20. mean VOLUME \% in entity is $1.85 \%$ of the AREA of the AU

is $\%$ of the AREA of the AU

is $\%$ of the AREA of the AU

is $\%$ of the AREA of the AU

is $\%$ of the AREA of the AU

is $\%$ of the AREA of the AU

is $\%$ of the AREA of the AU

is $\%$ of the AREA of the AU

is $6.83 \%$ of the AREA of the AU is $\%$ of the AREA of the AU 


\section{ALLOCATIONS OF POTENTIAL ADDITIONS TO RESERVES TO ECOSYSTEMS \\ Surface Allocations (uncertainty of a fixed value)}

1. Northeastern Glaciated Plains (NEGP) mean VOLUME \% in entity 34.00

2. Northern Glaciated Plains (NGPL) mean VOLUME \% in entity 53.00

3. Northwestern Great Plains (NWGP) mean VOLUME \% in entity 13.00

4. mean VOLUME \% in entity

5. mean VOLUME \% in entity

6. mean VOLUME \% in entity

7. mean VOLUME \% in entity

8. mean VOLUME \% in entity

9. mean VOLUME \% in entity

10. mean VOLUME \% in entity is $34.38 \%$ of the AREA of the AU $53.04 \%$ of the AREA of the AU $12.58 \%$ of the AREA of the AU

is $\%$ of the AREA of the AU

is $\%$ of the AREA of the AU

is $\%$ of the AREA of the AU

is $\%$ of the AREA of the AU

is $\%$ of the AREA of the AU

is $\%$ of the AREA of the AU is $\%$ of the AREA of the AU 
Table 7. Input parameters for the Northwest Transitional Continuous Oil Assessment Unit (50310165), Bakken Total Petroleum System, Williston Basin Province. [bcfg, billion cubic feet of gas; mmcfg, million cubic feet of gas; cfg, cubic feet of gas; mmbo, million barrels of oil; bo, barrel of oil; bliq, barrel of liquid; bngl, barrel of natural gas liquids; m, meters; AU, assessment unit; EUR, estimated ultimate recovery]

\section{INPUT DATA FORM FOR CONTINUOUS ACCUMULATIONS}

(version 1.2, July 20, 2012)

\section{IDENTIFICATION INFORMATION}

Assessment Geologist:

Region:

Province:

Total Petroleum System:

Assessment Unit:

Based on Data as of:

Notes from Assessor:
S. Gaswirth

North America

Williston Basin

Bakken

Northwest Transitional Continuous Oil

IHS Energy Group (2012), NRG Associates (2010)
Date: 29-Jan-13

Number: 5

Number: 5031

Number: 503101

Number: 50310165

Ancillary data from Pollastro (2008)

\section{CHARACTERISTICS OF ASSESSMENT UNIT}

Assessment-unit type: $\quad$ oil $(<20,000 \mathrm{cfg} / \mathrm{bo}) \frac{\mathrm{X}}{\text { heavy oil }(<10 \mathrm{API})}$ gas $(>20,000 \mathrm{cfg} / \mathrm{bo})$

Well type:

vertical horizontal $\mathrm{X}$

Major reservoir type (Choose one.):

shale coal

0.002 (mmbo for oil AU; bcfg for gas AU)

Minimum EUR per well

Number of tested wells:

56

Number of tested wells with EUR > minimum:

Historic success ratio, tested wells (\%)

\begin{tabular}{l}
54 \\
\hline 98 \\
\hline
\end{tabular}

\section{Assessment-Unit Probability:}

What is the probability that at least one well within the AU will have production capacity of at least the minimum EUR?

\section{NUMBER OF UNDRILLED WELLS WITH POTENTIAL FOR ADDITIONS TO RESERVES}

1. Productive area of accumulation (acres): (triangular)

calculated mean $1,866,667$ minimum $\quad 500,000$ mode $\quad 2,000,000$ maximum $3,100,000$

2. Uncertainty about average drainage area of wells (acres): (triangular)

calculated mean

440

minimum

320

mode

400

maximum

600

3. Percentage of total assessment-unit area that is untested (\%): (triangular)

calculated mean

97 minimum

94 mode

98.8 maximum

99.5

4. Percentage of untested assessment-unit area in sweet spots (\%): (triangular)

calculated mean

23

minimum

10

mode

15

maximum

45 


\section{ESTIMATED ULTIMATE RECOVERY (EUR) PER WELL}

\section{SWEET SPOTS}

5a. Future success ratio (\%): (triangular)

calculated mean

88

minimum

80

mode

90

maximum

95

5b. Uncertainty about average EUR (mmbo for oil; bcfg for gas): (shifted truncated lognormal)

calculated mean

0.154 minimum

0.075 median

0.15 maximum

0.25

\section{NON-SWEET SPOTS}

6a. Future success ratio (\%): (triangular)

calculated mean

43

minimum

10

mode

40

maximum

80

6b. Uncertainty about average EUR (mmbo for oil; bcfg for gas): (shifted truncated lognormal)

calculated mean

0.055 minimum

0.005 median

0.05 maximum

0.15

\section{UNCERTAINTY ABOUT AVERAGE COPRODUCT RATIOS FOR UNTESTED WELLS}

(triangular)

Oil assessment unit:

Gas/oil ratio (cfg/bo)

NGL/gas ratio (bngl/mmcfg)

Gas assessment unit:

Liquids/gas ratio (bliq/mmcfg)
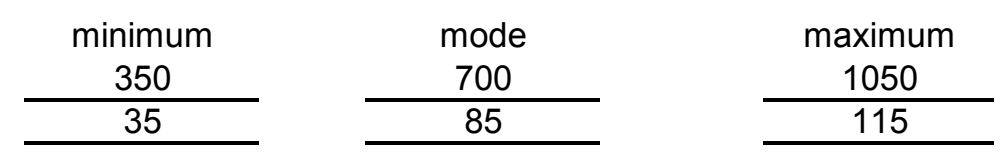


\section{SELECTED ANCILLARY DATA FOR UNTESTED WELLS}

(no specified distribution type)

Oil assessment unit:

API gravity of oil (degrees)

Sulfur content of oil (\%)

Depth $(\mathrm{m})$ of water (if applicable)

Drilling depth $(m)$

Gas assessment unit: Inert-gas content (\%)

$\mathrm{CO}_{2}$ content $(\%)$

Hydrogen sulfide content (\%)

Heating value (BTU)

Depth $(m)$ of water (if applicable)

Drilling depth $(m)$

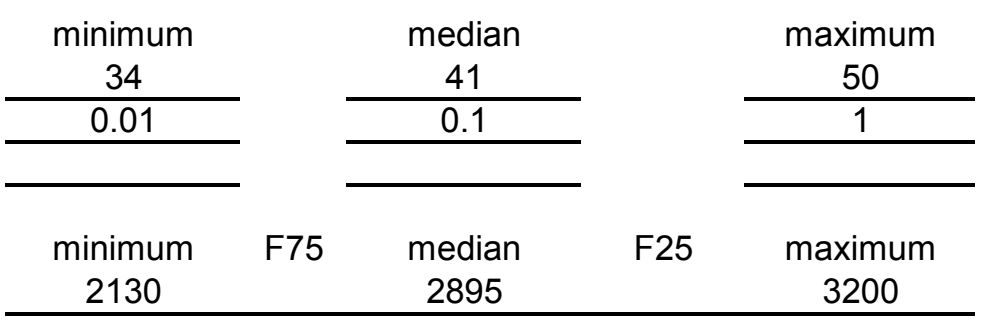

\begin{tabular}{|c|c|c|c|c|}
\hline minimum & & median & & maximum \\
\hline & & & & \\
\hline & & & & \\
\hline minimum & F75 & median & $\mathrm{F} 25$ & maximum \\
\hline
\end{tabular}

Completion practices:

1. Typical well-completion practices (conventional, open hole, open cavity, other)

2. Fraction of wells drilled that are typically stimulated

3. Predominant type of stimulation (none, frac, acid, other)

4. Historic fraction of wells drilled that are horizontal

\begin{tabular}{c}
$\frac{\text { open hole }}{1}$ \\
\hline frac \\
\hline 0.88 \\
\hline
\end{tabular}




\section{ALLOCATIONS OF POTENTIAL ADDITIONS TO RESERVES TO STATES \\ Surface Allocations (uncertainty of a fixed value)}

1. Montana

mean VOLUME \% in entity

2. North Dakota

mean VOLUME \% in entity

20.00

3.

mean VOLUME \% in entity

4.

mean VOLUME \% in entity

5.

mean VOLUME \% in entity

6.

mean VOLUME \% in entity

7.

mean VOLUME \% in entity

8.

mean VOLUME \% in entity

9.

mean VOLUME \% in entity

10.

mean VOLUME \% in entity

80.00 is

$82.36 \%$ of the AREA of the AU

is

$17.64 \%$ of the AREA of the AU

is $\%$ of the AREA of the AU

is $\%$ of the AREA of the AU

is $\%$ of the AREA of the AU

is $\%$ of the AREA of the AU

is $\%$ of the AREA of the AU

is $\%$ of the AREA of the AU

is $\%$ of the AREA of the AU

is $\%$ of the AREA of the AU 


\section{ALLOCATIONS OF POTENTIAL ADDITIONS TO RESERVES TO GENERAL LAND OWNERSHIPS Surface Allocations (uncertainty of a fixed value)}

1. Federal Lands

mean VOLUME \% in entity

2. Private Lands

mean VOLUME \% in entity

62.00

3. Tribal Lands

mean VOLUME \% in entity

27.91

4. Other Lands

mean VOLUME \% in entity

1.00

5. MT State Lands

mean VOLUME \% in entity

7.00

6. ND State Lands

mean VOLUME \% in entity

1.00

7.

mean VOLUME \% in entity

8.

mean VOLUME \% in entity

9.

mean VOLUME \% in entity

10.

mean VOLUME \% in entity is

$1.09 \%$ of the AREA of the AU

is

$62.12 \%$ of the AREA of the AU

is

$27.38 \%$ of the AREA of the AU

is

$0.37 \%$ of the AREA of the AU

is

$8.21 \%$ of the AREA of the AU

is

$0.83 \%$ of the AREA of the AU

is $\%$ of the AREA of the AU

is $\%$ of the AREA of the AU

is $\%$ of the AREA of the AU

is $\%$ of the AREA of the AU 


\section{ALLOCATIONS OF POTENTIAL ADDITIONS TO RESERVES TO FEDERAL LAND SUBDIVISIONS Surface Allocations (uncertainty of a fixed value)}

1. Bureau of Land Management (BLM) mean VOLUME \% in entity 0.12
2. BLM Wilderness Areas (BLMW) mean VOLUME \% in entity

3. BLM Roadless Areas (BLMR) mean VOLUME \% in entity

4. National Park Service (NPS) mean VOLUME \% in entity

5. NPS Wilderness Areas (NPSW) mean VOLUME \% in entity

6. NPS Protected Withdrawals (NPSP) mean VOLUME \% in entity

7. US Forest Service (FS) mean VOLUME \% in entity

8. USFS Wilderness Areas (FSW) mean VOLUME \% in entity

9. USFS Roadless Areas (FSR) mean VOLUME \% in entity

10. USFS Protected Withdrawals (FSP) mean VOLUME \% in entity is

$0.12 \%$ of the AREA of the AU

is $\%$ of the AREA of the AU

is $\%$ of the AREA of the AU

is $\%$ of the AREA of the AU $\%$ of the AREA of the AU $\%$ of the AREA of the AU $\%$ of the AREA of the AU $\%$ of the AREA of the AU $\%$ of the AREA of the AU

is $\%$ of the AREA of the AU 


\section{ALLOCATIONS OF POTENTIAL ADDITIONS TO RESERVES TO FEDERAL LAND SUBDIVISIONS} (continued)

11. US Fish and Wildlife Service (FWS) mean VOLUME \% in entity 0.97
12. USFWS Wilderness Areas (FWSW) mean VOLUME \% in entity

13. USFWS Protected Withdrawals (FWSP) mean VOLUME \% in entity

14. Wilderness Study Areas (WS) mean VOLUME \% in entity

15. Department of Energy (DOE) mean VOLUME \% in entity

16. Department of Defense (DOD) mean VOLUME \% in entity 0.00

17. Bureau of Reclamation (BOR) mean VOLUME \% in entity

18. Tennessee Valley Authority (TVA) mean VOLUME \% in entity

19. Other Federal mean VOLUME \% in entity

20. mean VOLUME \% in entity is

$0.97 \%$ of the AREA of the AU

is $\%$ of the AREA of the AU

is $\%$ of the AREA of the AU

is $\%$ of the AREA of the AU

is $\%$ of the AREA of the AU $0.00 \%$ of the AREA of the AU $\%$ of the AREA of the AU $\%$ of the AREA of the AU $\%$ of the AREA of the AU is $\%$ of the AREA of the AU 


\section{ALLOCATIONS OF POTENTIAL ADDITIONS TO RESERVES TO ECOSYSTEMS Surface Allocations (uncertainty of a fixed value)}

1. Northern Glaciated Plains (NGPL) mean VOLUME \% in entity 55.85

2. Northwestern Glaciated Plains (NWGL) mean VOLUME \% in entity 44.15

3. mean VOLUME \% in entity

4. mean VOLUME \% in entity

5. mean VOLUME \% in entity

6. mean VOLUME \% in entity

7. mean VOLUME \% in entity

8. mean VOLUME \% in entity

9. mean VOLUME \% in entity

10. mean VOLUME \% in entity is $55.85 \%$ of the AREA of the AU 44.15 $\%$ of the AREA of the AU $\%$ of the AREA of the AU

is $\%$ of the AREA of the AU $\%$ of the AREA of the AU $\%$ of the AREA of the AU $\%$ of the AREA of the AU $\%$ of the AREA of the AU $\%$ of the AREA of the AU is $\%$ of the AREA of the AU 
Table 8. Input parameters for the Three Forks Continuous Oil Assessment Unit (50310166), Bakken Total Petroleum System, Williston Basin Province. [bcfg, billion cubic feet of gas; mmcfg, million cubic feet of gas; cfg, cubic feet of gas; mmbo, million barrels of oil; bo, barrel of oil; bliq, barrel of liquid; bngl, barrel of natural gas liquids; m, meters; AU, assessment unit; EUR, estimated ultimate recovery]

\section{INPUT DATA FORM FOR CONTINUOUS ACCUMULATIONS}

(version 1.2, July 20, 2012)

IDENTIFICATION INFORMATION

Assessment Geologist:

Region:

K. Marra

North America

Date: 29-Jan-13

Province:

Williston Basin

Number: 5

Total Petroleum System:

Assessment Unit:

Bakken

Number: 5031

Three Forks Continuous Oil

Based on Data as of:

IHS Energy Group (2012), NRG Associates (2010)

Notes from Assessor:

Ancillary data from Pollastro (2008), Bakken as analog

\section{CHARACTERISTICS OF ASSESSMENT UNIT}

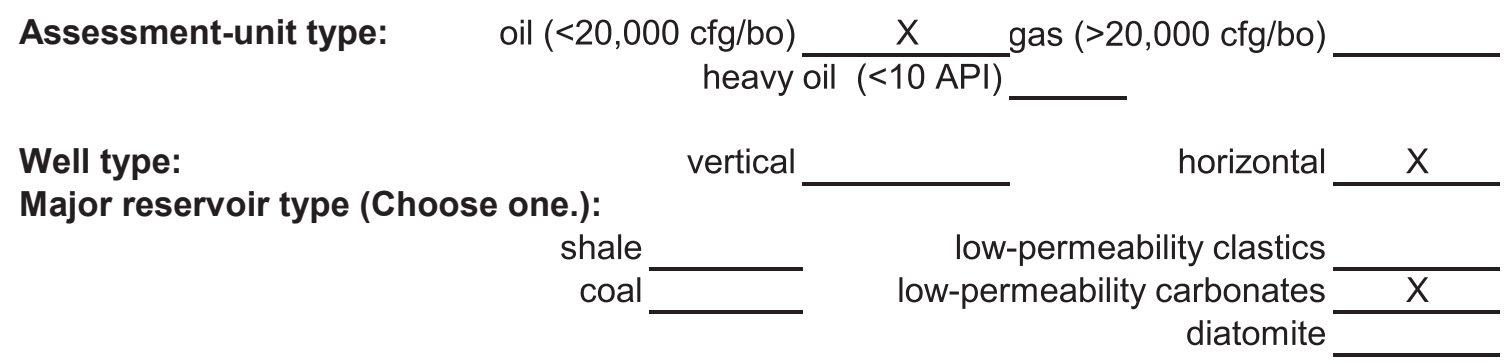

Minimum EUR per well $\quad 0.002$ (mmbo for oil AU; bcfg for gas AU)

Number of tested wells: $\quad 924$

Number of tested wells with EUR > minimum:

Historic success ratio, tested wells (\%)

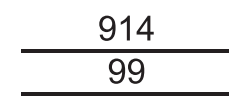

Assessment-Unit Probability:

What is the probability that at least one well within the AU will have production capacity of at least the minimum EUR?

\section{NUMBER OF UNDRILLED WELLS WITH POTENTIAL FOR ADDITIONS TO RESERVES}

1. Productive area of accumulation (acres): (triangular)

$$
\text { calculated mean } 13,333,333 \text { minimum } \underline{5,000,000} \text { mode } \underline{10,000,000} \text { maximum } \underline{25,000,000}
$$

2. Uncertainty about average drainage area of wells (acres): (triangular)

calculated mean

407 minimum

220 mode

400 maximum 600

3. Percentage of total assessment-unit area that is untested (\%): (triangular) calculated mean 95 minimum 89 mode 96.5 maximum 99.2

4. Percentage of untested assessment-unit area in sweet spots (\%): (triangular) calculated mean 50 minimum 10 mode 50 maximum 


\section{ESTIMATED ULTIMATE RECOVERY (EUR) PER WELL SWEET SPOTS}

5a. Future success ratio (\%): (triangular)

calculated mean

88 minimum

80

mode

90

maximum

95

5b. Uncertainty about average EUR (mmbo for oil; bcfg for gas): (shifted truncated lognormal)

calculated mean

0.222

minimum

0.18 median

0.22

maximum

0.275

\section{NON-SWEET SPOTS}

6a. Future success ratio (\%): (triangular)

calculated mean

43 minimum 10 mode 40 maximum 80

6b. Uncertainty about average EUR (mmbo for oil; bcfg for gas): (shifted truncated lognormal) calculated mean 0.085 minimum

0.01 median 0.08 maximum

0.2

\section{UNCERTAINTY ABOUT AVERAGE COPRODUCT RATIOS FOR UNTESTED WELLS}

(triangular)

Oil assessment unit:

Gas/oil ratio (cfg/bo)

NGL/gas ratio (bngl/mmcfg)
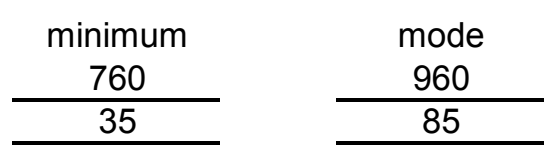

\begin{tabular}{c}
$\begin{array}{c}\text { maximum } \\
1160\end{array}$ \\
\hline 115 \\
\hline
\end{tabular}

Gas assessment unit:

Liquids/gas ratio (bliq/mmcfg) 


\section{SELECTED ANCILLARY DATA FOR UNTESTED WELLS}

(no specified distribution type)

Oil assessment unit:

API gravity of oil (degrees)

Sulfur content of oil (\%)

Depth $(\mathrm{m})$ of water (if applicable)

Drilling depth $(m)$
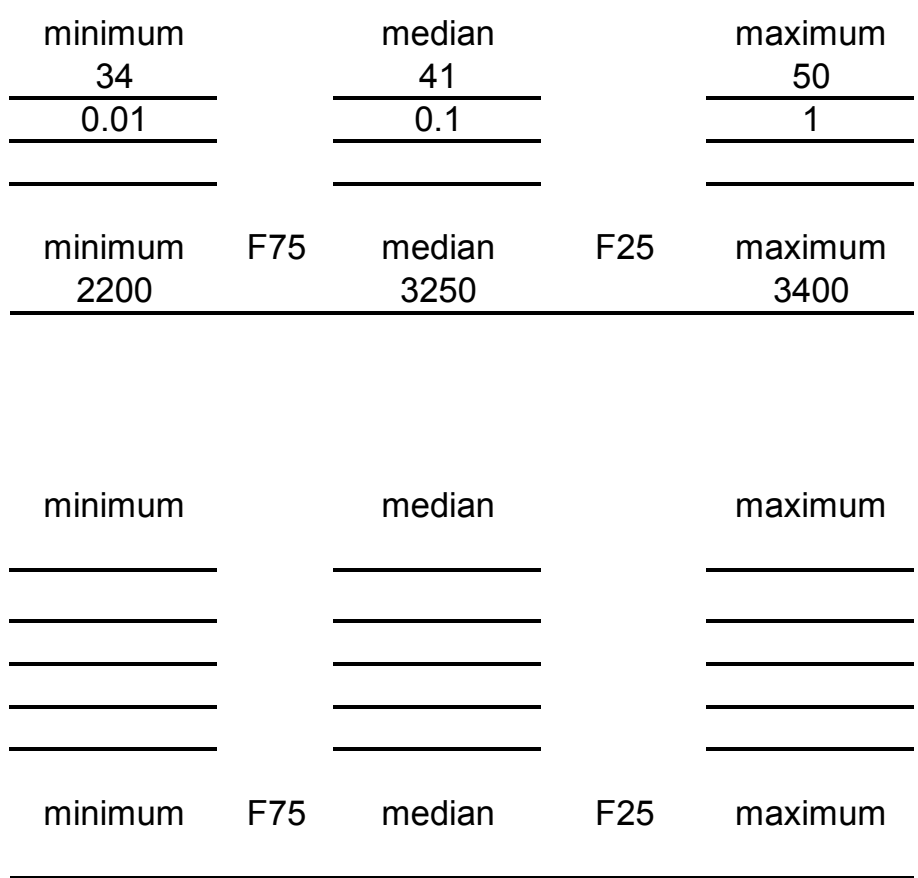

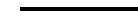

Gas assessment unit: Inert-gas content (\%)

$\mathrm{CO}_{2}$ content (\%)

Hydrogen sulfide content (\%)

Heating value (BTU)

Depth $(\mathrm{m})$ of water (if applicable)

Drilling depth $(m)$

(n)




\section{ALLOCATIONS OF POTENTIAL ADDITIONS TO RESERVES TO STATES \\ Surface Allocations (uncertainty of a fixed value)}

1. Montana

mean VOLUME \% in entity

2. North Dakota

mean VOLUME \% in entity

75.00

3.

mean VOLUME \% in entity

4.

mean VOLUME \% in entity

5.

mean VOLUME \% in entity

6.

mean VOLUME \% in entity

7.

mean VOLUME \% in entity

8.

mean VOLUME \% in entity

9.

mean VOLUME \% in entity

10.

mean VOLUME \% in entity is $\quad 25.18 \%$ of the AREA of the AU

is $\quad 74.82 \%$ of the AREA of the AU

is $\%$ of the AREA of the AU

is $\%$ of the AREA of the AU

is $\%$ of the AREA of the AU

is $\%$ of the AREA of the AU

is $\%$ of the AREA of the AU

is $\%$ of the AREA of the AU

is $\%$ of the AREA of the AU

is $\%$ of the AREA of the AU 


\section{ALLOCATIONS OF POTENTIAL ADDITIONS TO RESERVES TO GENERAL LAND OWNERSHIPS Surface Allocations (uncertainty of a fixed value)}

1. Federal Lands

mean VOLUME \% in entity

2. Private Lands

mean VOLUME \% in entity

78.00

3. Tribal Lands

mean VOLUME \% in entity

10.00

4. Other Lands

mean VOLUME \% in entity

1.00

5. MT State Lands

mean VOLUME \% in entity

2.00

6. ND State Lands

mean VOLUME \% in entity

2.00

7.

mean VOLUME \% in entity

8.

mean VOLUME \% in entity

9.

mean VOLUME \% in entity

10.

mean VOLUME \% in entity is $\quad 6.68 \%$ of the AREA of the AU

is $\quad 77.56 \%$ of the AREA of the AU

is $\quad 10.42 \%$ of the AREA of the AU

is $\quad 1.03 \%$ of the AREA of the AU

is $\quad 1.85 \%$ of the AREA of the AU

is $\quad 2.46 \%$ of the AREA of the AU

is $\%$ of the AREA of the AU

is $\%$ of the AREA of the AU

is $\%$ of the AREA of the AU

is $\%$ of the AREA of the AU 


\section{ALLOCATIONS OF POTENTIAL ADDITIONS TO RESERVES TO FEDERAL LAND SUBDIVISIONS Surface Allocations (uncertainty of a fixed value)}

1. Bureau of Land Management (BLM) mean VOLUME \% in entity 0.50

2. BLM Wilderness Areas (BLMW) mean VOLUME \% in entity

3. BLM Roadless Areas (BLMR) mean VOLUME \% in entity

4. National Park Service (NPS) mean VOLUME \% in entity 0.30

5. NPS Wilderness Areas (NPSW) mean VOLUME \% in entity

6. NPS Protected Withdrawals (NPSP) mean VOLUME \% in entity

7. US Forest Service (FS) mean VOLUME \% in entity 3.20

8. USFS Wilderness Areas (FSW) mean VOLUME \% in entity

9. USFS Roadless Areas (FSR) mean VOLUME \% in entity

10. USFS Protected Withdrawals (FSP) mean VOLUME \% in entity is $\quad 0.46 \%$ of the AREA of the AU

is $\%$ of the AREA of the AU

is $\%$ of the AREA of the AU

is $\quad 0.28 \%$ of the AREA of the AU

is $\%$ of the AREA of the AU

is $\%$ of the AREA of the AU

is $3.14 \%$ of the AREA of the AU

is $\%$ of the AREA of the AU

is $\%$ of the AREA of the AU

is $\%$ of the AREA of the AU 


\section{ALLOCATIONS OF POTENTIAL ADDITIONS TO RESERVES TO FEDERAL LAND SUBDIVISIONS (continued)}

11. US Fish and Wildlife Service (FWS) mean VOLUME \% in entity 1.00

12. USFWS Wilderness Areas (FWSW) mean VOLUME \% in entity

13. USFWS Protected Withdrawals (FWSP) mean VOLUME \% in entity

14. Wilderness Study Areas (WS) mean VOLUME \% in entity

15. Department of Energy (DOE) mean VOLUME \% in entity

16. Department of Defense (DOD) mean VOLUME \% in entity 0.00

17. Bureau of Reclamation (BOR) mean VOLUME \% in entity

18. Tennessee Valley Authority (TVA) mean VOLUME \% in entity

19. Other Federal mean VOLUME \% in entity 2.00

20. mean VOLUME \% in entity is $\quad 1.05 \%$ of the AREA of the AU

is $\%$ of the AREA of the AU

is $\%$ of the AREA of the AU

is $\%$ of the AREA of the AU

is $\%$ of the AREA of the AU

is $\quad 0.00 \%$ of the AREA of the AU

is $\%$ of the AREA of the AU

is $\%$ of the AREA of the AU

is $1.75 \%$ of the AREA of the AU

is $\%$ of the AREA of the AU 


\section{ALLOCATIONS OF POTENTIAL ADDITIONS TO RESERVES TO ECOSYSTEMS Surface Allocations (uncertainty of a fixed value)}

1. Northeastern Glaciated Plains (NEGP) mean VOLUME \% in entity

25.16

2. Northern Glaciated Plains (NGPL) mean VOLUME \% in entity 41.50

3. Northwestern Glaciated Plains (NWGL) mean VOLUME \% in entity 8.62

4. Northwestern Great Plains (NWGP) mean VOLUME \% in entity 24.66

5. Powder River Basin (PRBA) mean VOLUME \% in entity 0.06

6. mean VOLUME \% in entity

7. mean VOLUME \% in entity

8. mean VOLUME \% in entity

9. mean VOLUME \% in entity

10. mean VOLUME \% in entity is $\quad 25.16 \%$ of the AREA of the AU

is $\quad 41.50 \%$ of the AREA of the AU

is $\quad 8.62 \%$ of the AREA of the AU

is $\quad 24.66 \%$ of the AREA of the AU

is $\quad 0.07 \%$ of the AREA of the AU

is $\%$ of the AREA of the AU

is $\%$ of the AREA of the AU

is $\%$ of the AREA of the AU

is $\%$ of the AREA of the AU

is $\%$ of the AREA of the AU 